\title{
Addressing the Federal-State-Local Interface Issues During a Catastrophic Event Such as an Anthrax Attack
}

SL Stein

AM Lesperance

JF Upton

February 2009

Prepared for the U.S. Department of Defense, Defense Threat Reduction Agency under Contract IACRO\#B0844731 and the U.S. Department of Homeland Security

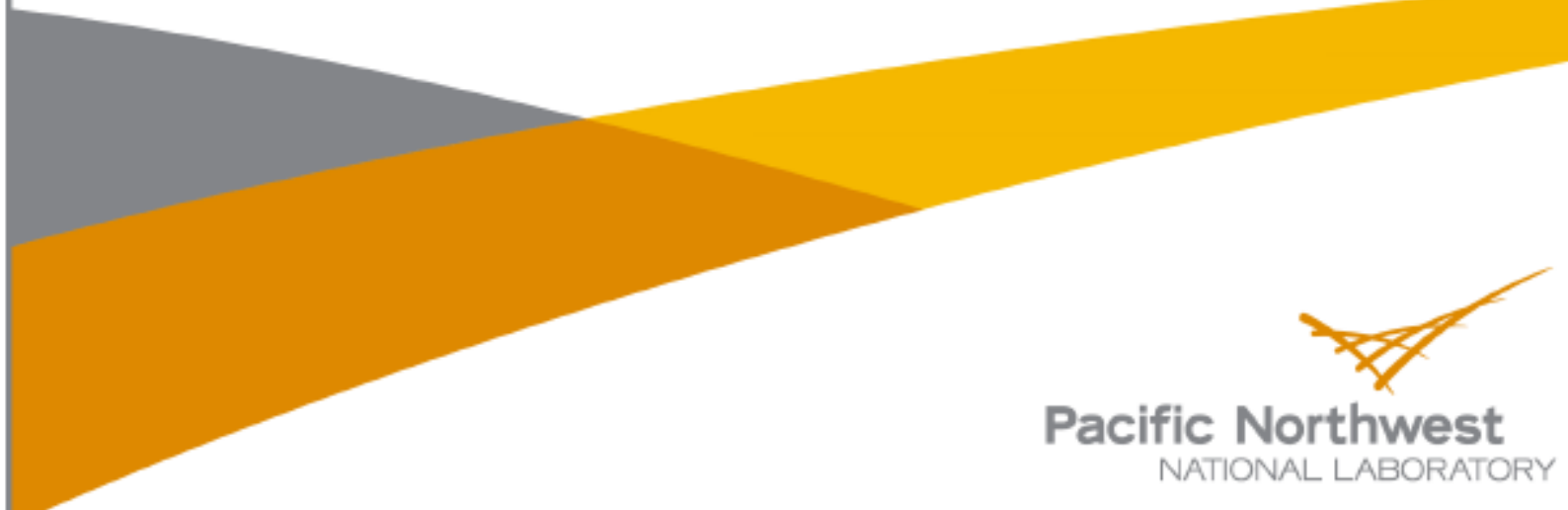

Supported by the Northwest Regional Technology Center for Homeland Security 


\title{
Acknowledgements
}

The authors would like to acknowledge and thank the regional emergency managers, pubic health and medical services representatives, and local, state and federal decision makers, both civilian and military, who participated in the this workshop.

Their contributions of operational perspective and technical expertise were invaluable.

We would also like to thank the U.S. Department of Homeland Security

and the U.S. Department of Defense $(D \circ D)$ for funding the Interagency

Biological Restoration Demonstration program that supported the workshop.

\section{DISCLAIMER}

This report was prepared as an account of work sponsored by an agency of the United States Government. Neither the United States Government nor any agency thereof, nor Battelle Memorial Institute, nor any of their employees, makes any warranty, express or implied, or assumes any legal liability or responsibility for the accuracy, completeness, or usefulness of any information, apparatus, product, or process disclosed, or represents that its use would not infringe privately owned rights. Reference herein to any specific commercial product, process, or service by trade name, trademark, manufacturer, or otherwise does not necessarily constitute or imply its endorsement, recommendation, or favoring by the United States Government or any agency thereof, or Battelle Memorial Institute. The views and opinions of authors expressed herein do not necessarily state or reflect those of the United States Government or any agency thereof.

\author{
PACIFIC NORTHWEST NATIONAL LABORATORY \\ operated by \\ BATTELLE \\ for the \\ UNITED STATES DEPARTMENT OF ENERGY \\ under Contract DE-AC05-76RL01830
}

Printed in the United States of America

$$
\begin{aligned}
& \text { Available to DOE and DOE contractors from the } \\
& \text { Office of Scientific and Technical Information, } \\
& \text { P.O. Box 62, Oak Ridge, TN 37831-0062; } \\
& \text { ph: (865) 576-8401 } \\
& \text { fax: (865) 576-5728 } \\
& \text { email: reports@adonis.osti.gov }
\end{aligned}
$$

\footnotetext{
Available to the public from the National Technical Information Service, U.S. Department of Commerce, 5285 Port Royal Rd., Springfield, VA 22161 ph: (800) 553-6847 fax: (703) 605-6900 email: orders@ntis.fedworld.gov online ordering: http://www.ntis.gov/ordering.htm
} 


\section{Executive Summary}

On October 9, 2008, federal, state, and local policy makers, emergency managers, and medical and public health officials convened in Seattle, Washington for a workshop entitled Addressing the Federal-State-Local Interface Issues during a Catastrophic Event Such as an Anthrax Attack. The day-long symposium was sponsored by the Interagency Biological Restoration Demonstration (IBRD), a collaborative regional program jointly funded by the U.S. Department of Homeland Security (DHS) and the U.S. Department of Defense (DoD). It was intended to generate dialogue about recovery and restoration through a discussion about the challenges that impact entire communities_-including people, infrastructure, and critical systems_following a biological incident.

Discussions began with a presentation by Rear-Admiral (RADM) John Currier on the role of the Principal Federal Official (PFO) during a catastrophic event, followed by interactive group sessions covering:

- Decision-making, prioritization, and command and control

- Public health/medical services

- Community resiliency and continuity of government.

During the interactive sessions, the following key issues emerged:

- Local representation in the Joint Field Office (JFO)

- JFO transition to the Long-Term Recovery Office

- Process for prioritization of needs

- Process for regional coordination

- Prioritization-process and federal/military intervention

- Allocation of limited resources

- Re-entry decision and consistency

- Importance of maintaining a healthy hospital system

- Need for a process to establish a consensus on when it is safe to re-enter-across all jurisdictions, including the military

- Insurance coverage for both private businesses and individuals

- Interaction between the government and industry.

To aid the IBRD program's efforts and inform the development of a blueprint for recovery from a biological incident, the following report provides further detail of the discussions in which these key issues were identified during the workshop. 


\section{Contents}

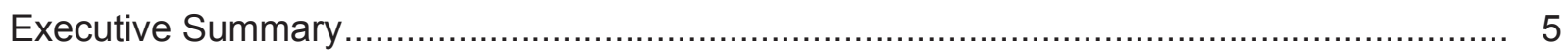

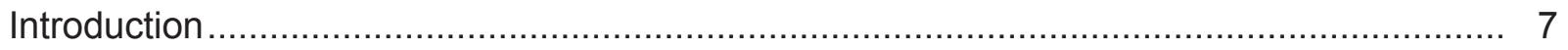



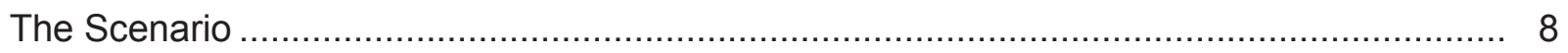

Role of the Principal Federal Official ………….................................................... 9

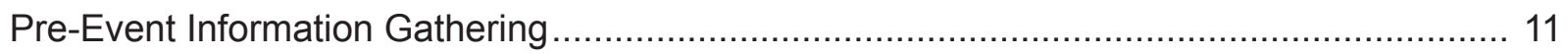

Focus Area 1: Decision-Making, Prioritization, and Command and Control.......................... 14

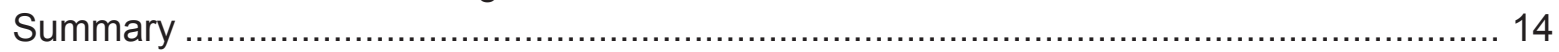

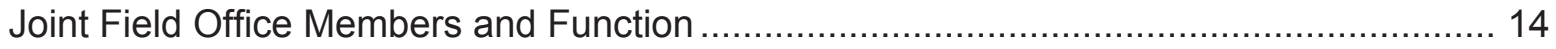

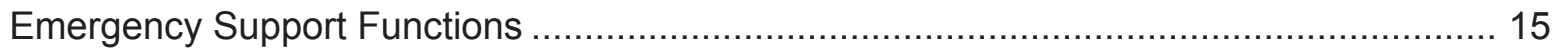

ESF-14 - Long-Term Community Recovery …………..................................... 15

ESF-8 - Public Health and Medical Services ........................................................ 16

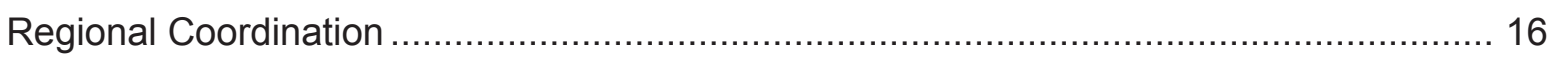

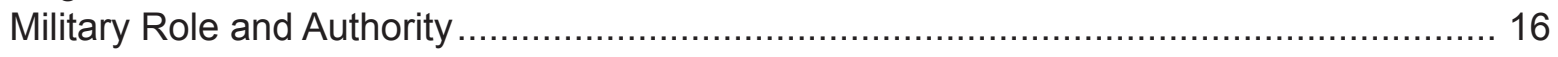

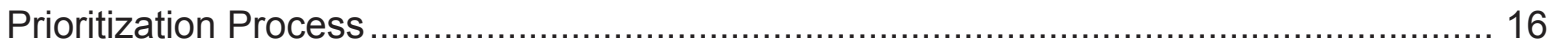





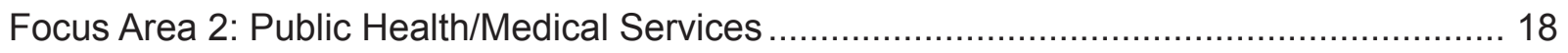

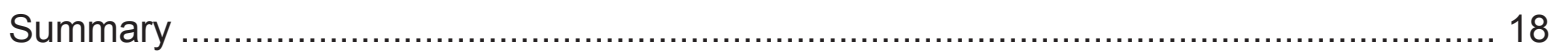

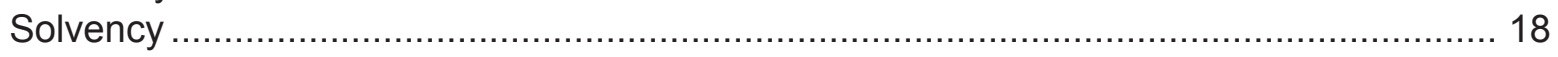

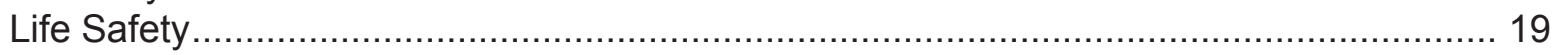

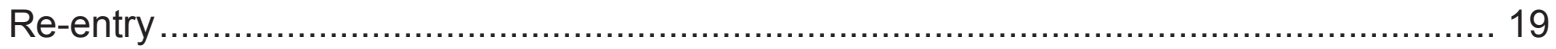

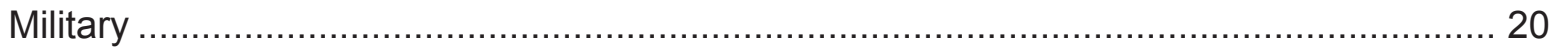



Results from Community Resilience Workshops …….................................................... 20

Focus Area 3: Community Resiliency and Continuity of Government................................... 21

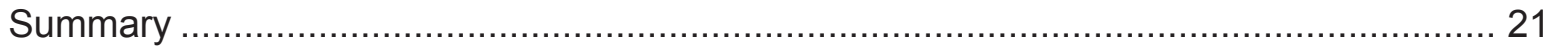

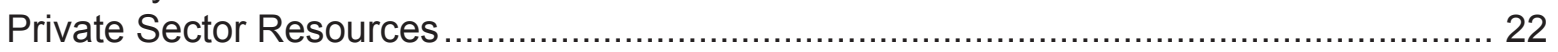

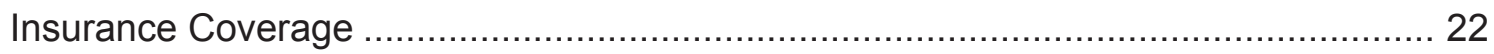



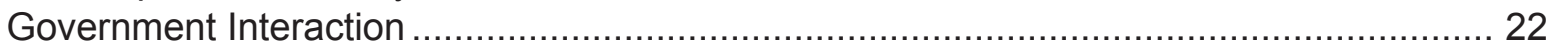



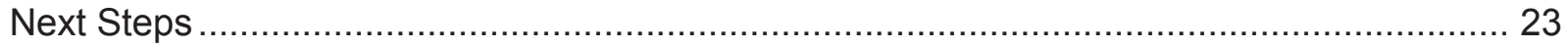



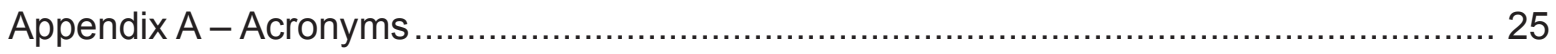

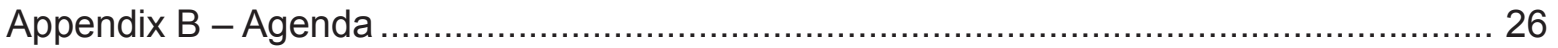

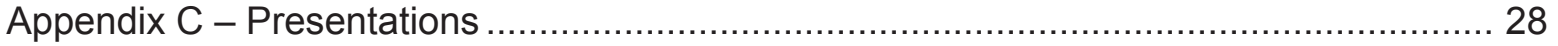



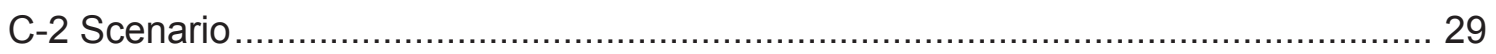

C-3 Role of the Principal Federal Official.................................................................... 31



C-5 Community Resilience ............................................................................. 38

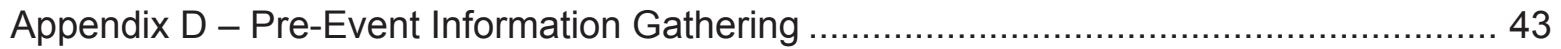

Appendix E - References on Anthrax............................................................... 46

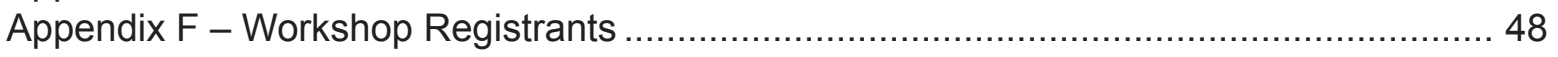




\section{Introduction}

On October 9, 2008, federal, state, and local policy makers, emergency managers, and medical and public health officials convened in Seattle, Washington, for the workshop Addressing the Federal-State-Local Interface Issues during a Catastrophic Event Such as an Anthrax Attack. The interactive workshop was sponsored by the Interagency Biological Restoration Demonstration (IBRD), a collaborative regional program jointly funded by the U.S. Department of Homeland Security (DHS) and the U.S. Department of Defense (DoD). The IBRD program works to develop policies, methods, plans, and applied technologies to restore large urban areas, DoD installations, and critical infrastructures following the release of a biological agent.

Over the course of previous IBRD sponsored events, local emergency management personnel have frequently raised questions about the roles, responsibilities, and interfaces between the federal government and state and local authorities during recovery from a catastrophic event such as an anthrax attack. Some of these questions included:

- What is the role of each of the federal agencies (nationally and locally)?

- How do federal agencies fit into Incident Command?

- How are federal agency roles coordinated with one another at the federal level?

- What would Stafford Act assistance and non-Stafford Act assistance look like from the federal government during the recovery period after a wide-scale, largely unprecedented event?

The objective of this workshop was to address some of these questions by clarifying and sharing information about the federal government's role during a catastrophic event such as a largescale anthrax attack. It also sought to define and understand the command and control structure among federal, state, and local organizations, and to begin developing a conduct of operations that illustrates the relationships, decision frameworks, and resources of the local, state, and federal agencies. Participants discussed key challenges, issues, and gaps, as well as how they might be addressed. Observers were also present during group discussions, and had the opportunity to submit written questions for the group to consider. A complete list of registrants is included in Appendix F.

The following sections provide summaries of the presentations and detail the discussions held throughout the day.

\section{Opening Remarks}

Ann Lesperance, of the Pacific Northwest National Laboratory (PNNL), opened the meeting by introducing the purpose of the workshop and the IBRD program. She explained that the workshop grew out of comments and concerns from attendees, many of whom had participated in

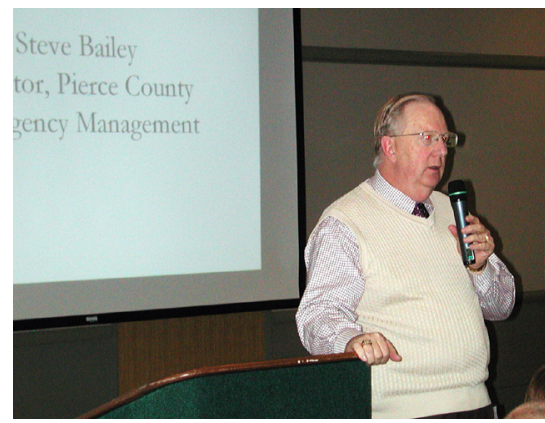
previous project activities.

Next, Steve Bailey, Director of Pierce County Emergency Management, welcomed


attendees on behalf of local emergency management and the Seattle Urban Area Security Initiative (UASI). He commended the IBRD program for focusing on important issues, "The science involved in responding to a biological attack at the federal level is robust, but fractured among many agencies," he said. 
Mr. Bailey continued by stating that several questions need to be addressed, including:

- How are the command and control aspects handled?

- What does the federal response mean to the local level?

- What are the priorities for recovery, and who makes that decision?

Mr. Bailey noted that policymakers at the local level are not currently well organized to make decisions about how to move the recovery forward. He cited the need to identify a way to come together at the officials' level to conduct a long-term recovery at the regional level. "We've done transit and some environmental issues regionally, but we've never done emergency management regionally," he stated.

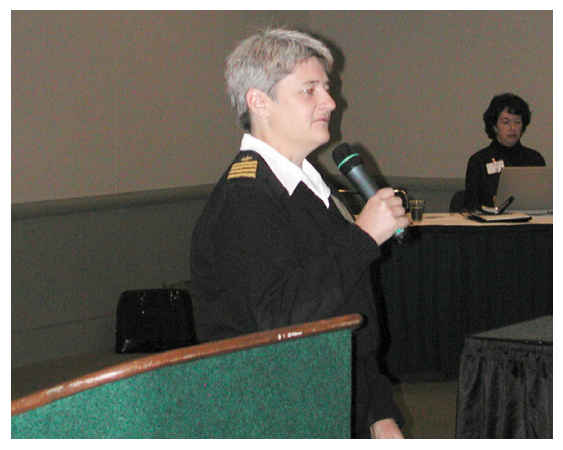

After Mr. Bailey's presentation concluded, Captain Julie Sadovich, RN Ph.D., Director, Emergency Management and Medical Response Integration (EMMRI), DHS Office of Health Affairs (OHA), welcomed participants on behalf of DHS. OHA supports medical response research and makes implementation easier to achieve. The agency is developing public/private partnerships to create an environment in which shared decision-making can happen, not only during catastrophic events, but also on a daily basis. OHA will be working with the IBRD program as it moves forward.

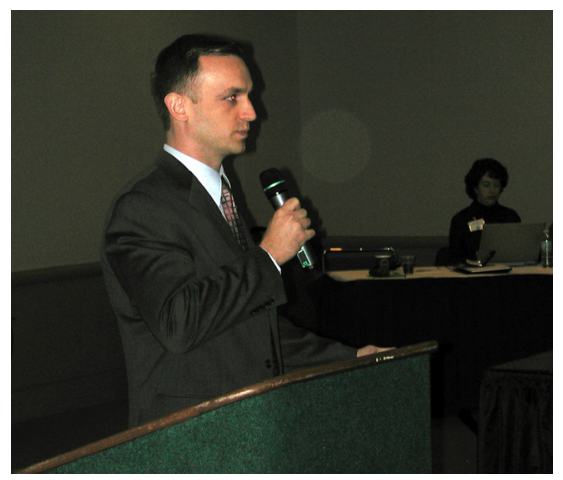

Next, Ryan Madden, Defense Threat Reduction Agency (DTRA), co-manager of the project, provided an overview of the IBRD program. He reiterated that the goal of the project is to reduce the time and resources necessary to recover and restore wide urban areas, military installations, and critical infrastructure following a biological incident. Mr. Madden commented that "The Seattle urban area is an ideal location for a pilot, with critical infrastructures and military installations, and lessons learned here can be shared nationally. This is a unique program with local and national benefits."

\section{The Scenario}

To set the framework for discussion, Mr. Steve Stein, workshop moderator and Director of the Northwest Regional Technology Center for Homeland Security, provided a high-level overview of the scenario used to address questions posed in the workshop. He stressed the importance of working with the scenario, and requested that all participants share their experience and expertise during group discussions. The scenario, which was based on National Planning Scenario 2 Biological Attack-Aerosol Anthrax and tailored for the Pacific Northwest, begins at three months after the event. Its key elements are as follows:

- Covert anthrax aerosol attacks are initiated by an organized worldwide terrorist group. Tens of thousands of people are exposed and thousands of deaths result.

- State of emergency is declared by the president and Washington State governor. Significant federal support is on scene.

- There is significant contamination in affected areas, including critical infrastructure, commercial, military and private property.

- Approximate area of contamination $=2$ areas of 10 square miles each 
- 500 buildings contaminated (public and private)

- Ports affected (Seattle, Tacoma)

- Local government operations relocated

- Basic services affected

- Local businesses affected

- Local military installations affected (Ft Lewis/ McChord Air Force Base)

A complete description of the scenario is located in Appendix C-2.

\section{Role of the Principal Federal Official}

In preparation for the workshop, local and state emergency management representatives requested additional information regarding the roles and responsibilities of the Principal Federal Official (PFO) during recovery from a biological attack. RADM John Currier, U.S. Coast Guard (USCG), the designated PFO for Region $E^{1}$,

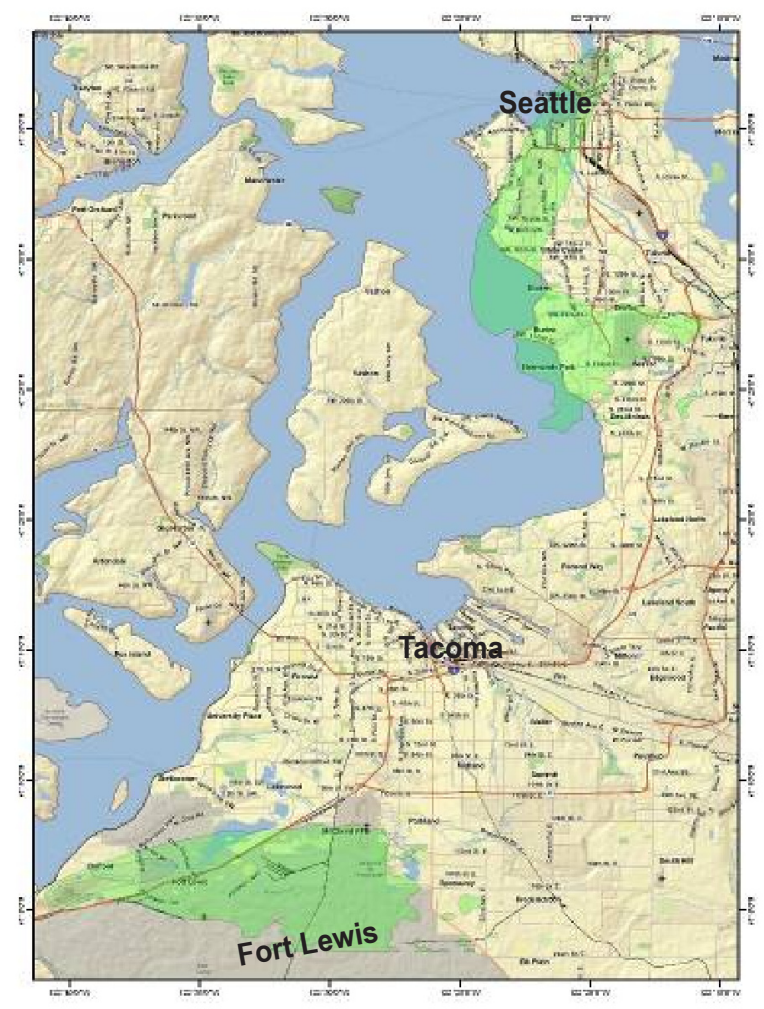
which includes Federal Regions IX and X, agreed to provide an overview of his role.

RADM Currier shared his beliefs about how the federal government would respond to a pandemic or major bio-threat incident. He commended the participants for their engagement in the workshop but cautioned that the value of the exercise is in the processes and strategies rather than tactical operations. "We are all tactical by nature, but the workshop is about processes and how agencies get together, work together, and fit together," he noted. He also urged participants to frame planning assumptions and articulated his own, which are as follows:

- Everyone here is a good American citizen, and all officials from the president down are interested in the wellbeing of all Americans

- Federal response is here to support the tactical level.

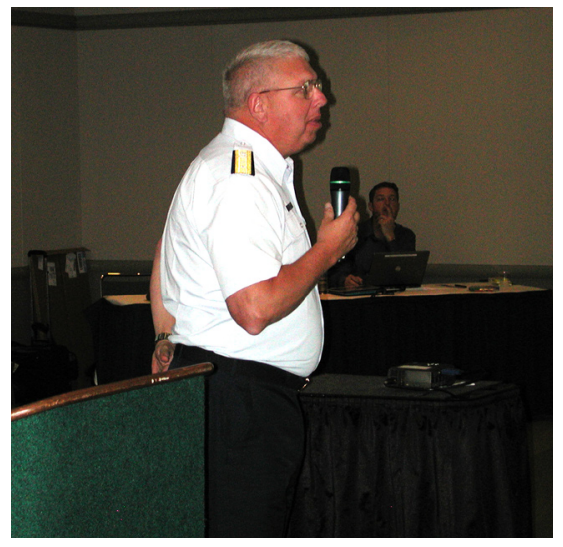

\section{Role of DHS in Recovery}

Based on the Homeland Security Act of 2002, the DHS Secretary leads DHS in executing its key missions. One of those missions is to minimize the damage and assist recovery from terrorist attacks in the U.S. Another is to act as a focal point for natural and human-made crises and emergency planning. That focal point is at the strategic level in Washington, D.C.

The Secretary's role is further defined in Homeland Security Presidential Directive-5, which states that the Secretary is the PFO for domestic incident management. Through a unified command at the federal level, the Secretary:

\footnotetext{
${ }^{1}$ Region E includes Alaska, Arizona, California, Hawaii, Idaho, Nevada, Oregon, and Washington.
} 
- Is responsible for coordinating federal operations within the U.S. to prepare for, respond to, and recover from terrorist attacks, major disasters, and other emergencies

- Coordinates the federal government's resources to respond to or recover from terrorist attacks, major disasters, and other emergencies.

\section{Role of the PFO}

In his role as PFO, RADM Currier supports the governor, who supports the county, who supports the locals in service delivery. He does not work at the point of service delivery.

According to the National Response Framework, the framework under which all emergencies are managed, the PFO serves as the DHS Secretary's direct regional representative. The position may be delegated when:

- Catastrophic or unusually complex incidents require extraordinary coordination

- The Federal Emergency Management Agency (FEMA) should not be the lead agency, such as in the case of a pandemic outbreak

- Major non-Stafford Act responses occur even though the response may include a Stafford Act $^{2}$ component.

The PFO interfaces with federal, state, tribal, and local officials on the overall federal incident management strategy and serves as the primary point of contact for situational awareness for the Secretary. The PFO on site provides information management support for the Secretary and federal government, including DoD, as well as media relations assistance and support to the Federal Command Officer. The Centers for Disease Control and Prevention (CDC), U.S. Environmental Protection Agency (EPA), and other federal agencies would provide support as well, reaching as far down as the local emergency operations center (EOC). In the event of a terrorist act, DHS would partner with the Department of Justice to form a unified command at the state level.

Federal agencies do not come in and act unilaterally. They do not act at the point of service delivery unless the state and local governments cannot provide essential services. Katrina response is not the model for federal response. Flood response provides a more appropriate model. Following a flood, money and services come in to support the locals at the point of service delivery. If there is a well-defined emergency management protocol, the federal government will not step in to take command.

Authorities are grounded in policy, like the National Strategy and National Implementation Plan for pandemic influenza. The National Response Framework deals with all major emergencies at the national level. Everything operates on the Integrated Command System (ICS). For
Region E Pandemic Influenza \& Biological Event PFO Team (Federal Regions IX and $X$ )

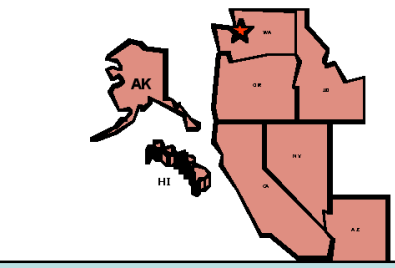

\begin{tabular}{|c|c|c|}
\hline \multicolumn{3}{|c|}{ Unified Coordination Group } \\
\hline RADM Currier & RADM O'Carroll & Mr. Nunn \\
Region E PFO & HHS Senior Official & FEMA FCO \\
\hline \hline COLArmstrong & COL Stanley & RADM Zukunft \\
DoD DCO (Reg IX) & DoD DCO (Reg X) & Dep PFO, Reg IX \\
\hline Ms. Reinerston & TBD & LTG Fraser \\
Dep PFO, Reg $X$ & SFLEO & JTF Alaska \\
\hline
\end{tabular}

Ms. Warren

ExecAssist

Mr. Gardner DHS IP LNO

\footnotetext{
2 The Robert T. Stafford Disaster Relief and Emergency Assistance Act, Public Law 93-288, as amended. The the Stafford Act is the principal legislation governing the federal response to disasters within the United States. The act spells out-among other things-how disasters are declared, the types of assistance to be provided, and the cost-sharing arrangements between federal, state, and local governments.
} 
pandemic and chemical/biological incidents, Washington State falls in Region E. Local officials need to recognize that people in charge at the federal level will change as military leaders transition in and out. The PFO sits in the Joint Field Office (JFO), with contacts at the state level, and reports, most likely, daily at the National PFO level, into the Homeland Security Council.

\section{Needs}

RADM Currier expressed the need for effective and integrated policies, strategic communications planning, effective decision-making processes, and integration of federal departments/ agencies with state, local, tribal, private sector, and other non-government organizations. He also stressed the need to conduct exercises, and closed by recognizing that the participants are the heroes on a daily basis.

\section{Question and Answer}

One participant asked what happens when multiple states are affected and vying for resources. Does the federal government step in to prioritize resources? RADM Currier indicated that priorities are determined above his level, with Congressional and state involvement. The local level has huge responsibilities in the initial response. It takes at least 72 hours for the federal government to enter the scene following a disaster. Local governments must be prepared to manage a response for those first 72 hours on their own.

Another participant noted that the same conflicts (i.e., vying for resources), will reside at the county or local levels. It is not assumed that this is the role of the governor. Processes to manage conflicts must be worked on now.

RADM Currier responded by saying that FEMA has changed radically since Katrina, indicating that he has never seen a group of people who work so hard for America and get so little appreciation. They are orders of magnitude better than they were before Katrina. FEMA is the state and local level entry to the federal government.

\section{Pre-Event Information Gathering}

Following RADM Currier's presentation, Steve Stein discussed how information was gathered to inform workshop development. Prior to the workshop, interviews were conducted with local, state, and federal emergency management staff to gain an understanding of critical issues. Information was provided by:

- Locals, including emergency management in King, Pierce, and Snohomish counties and the city of Seattle

- Washington State, including staff from the Emergency Management Department

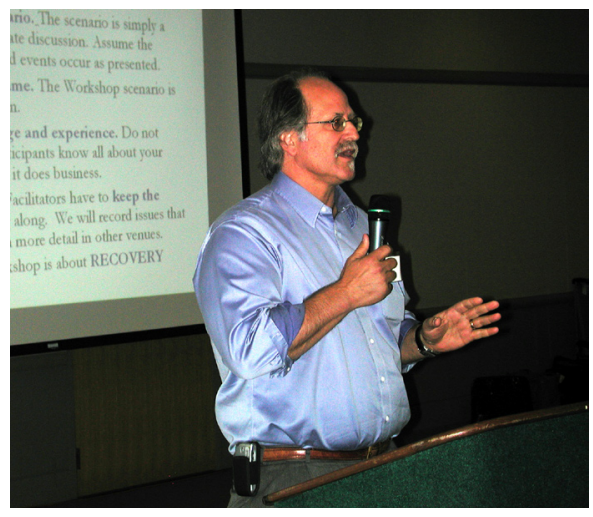

- Federal agencies, including FEMA Region 10 and EPA Region 10.

The goal of the pre-workshop interviews was to identify gaps, issues, and points of conflict related to the federal role in recovery from an anthrax event.

The three major focus areas identified and validated during the interview process were:

- Decision-making, prioritization, and command and control

- Public health and medical services

- Community resilience and continuity of government. 
Based on the information gathered, the following questions were developed and separated into each of the three focus areas.

\section{Decision-making, prioritization, and command and control}

- How is a unified command set up? What does it include? Who are the advisors?

- How are decisions made and who makes them? Decisions include prioritization of cleanup and efforts to support economic recovery, development and communication of a common message, waste management, and the ability of federal and state agencies to trump locals.

- Is life safety the top priority in the context of recovery?

- What is the long-term role of the JFO?

- Who coordinates field assets?

\section{Public health and medical services}

- Who decides how clean is clean?

- Who decides standards for safe occupancy?

- Who is responsible for tracking/monitoring people who have been exposed? Who pays?

- How do we maintain solvency in the medical system?

\section{Community resilience and continuity of government}

- Who pays for relocation of individuals and buildings outside the contamination area?

- How do you assure people it's safe to return?

- What services are maintained?

- Who sets policies for those in need (uninsured, displaced workers, displaced residents)?

- Who makes the declaration that facilities are unsafe for occupancy?

- What does the Stafford Act provide?

The protocol used during the interviews is included in Appendix D. The presentation can be found in Appendix C-4.

These interviews were also used to develop the draft recovery organization chart that follows. 


\section{Draft for Discussion Purposes only}

\section{Recovery Organizational Structure}

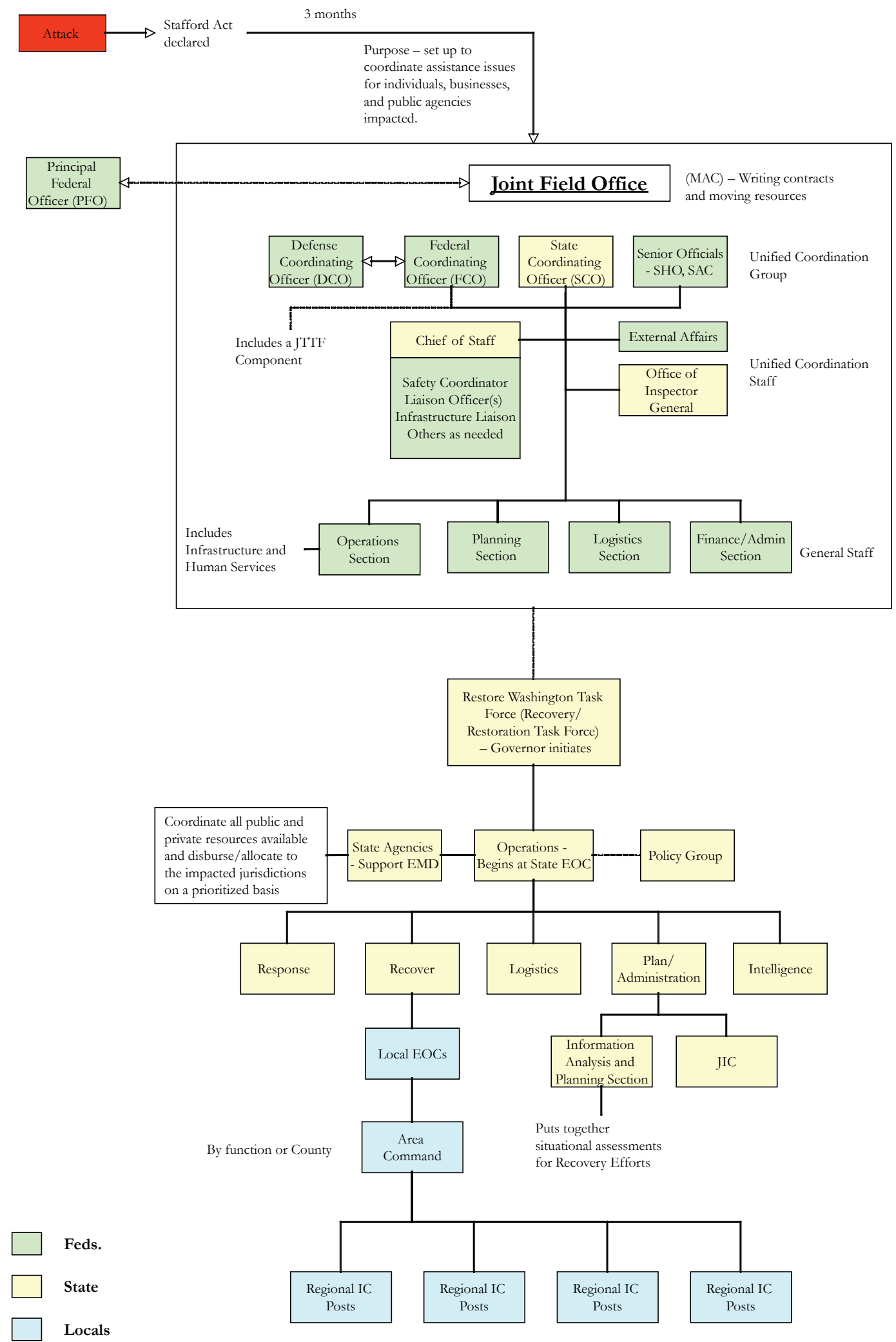




\section{Focus Area 1: Decision-Making, Prioritization, and Command and Control}

\section{Summary}

Decision-making, prioritization, and command and control issues caused the most concern and confusion among participants. The major related issues discussed at the workshop included:

- Local representation in the JFO

- JFO transition to the Long-Term Recovery Office

- Process for prioritization of needs

- Process for regional coordination

- Prioritization-process and federal/military intervention

- Allocation of limited resources

- Re-entry decision and consistency.

The following further details the discussion, including questions posed by participants and moderators and answers provided by appropriate agency representatives.

\section{Joint Field Office Members and Function}

One participant asked how the role of the JFO changes during recovery. A FEMA representative indicated that after three months, the area would be under a JFO, but state operational requirements would dictate how long the JFO remains in place. Once the work gets beyond sampling and health issues, the JFO may either remain or transition.

A moderator noted that at some point there will be a transition. What does that look like? What's the venue to discuss actions with the federal agencies when they are no longer being coordinated? A USCG representative said the state is the key to transition, and that the JFO will be around as long as the state wants it around. He noted that the timing of the JFO transition would be a joint decision with the state and locals. For a long-term recovery effort, a Long-Term Recovery Office would help with coordination. Whether it is a JFO or Long-Term Recovery Office, the same coordination functions apply. FEMA will do all it can to keep that operation open as long as it is needed. If done correctly, the transition would have no significant effect. The other federal agencies work with the JFO or Long-Term Recovery Office in the same way.

Another participant then asked whether there would be a single location for this function, or would the state set up a recovery office? State representatives indicated that the state would have a similar recovery authority. There is currently a task force at the governor's office, the Washington Restoration Task Force, whose intent is to mend the social, economic, and government fabric as quickly as possible. The state would be a part of the JFO or Long-Term Recovery Office.

The USCG would also set up marine recovery long-term response which starts as a marine recovery unit to get the ports back up and running and transitions to long-term.

A moderator asked whether participants were comfortable with the JFO prioritizing needs. Should the process be more local? A local emergency management official said that was the objective of the workshop; he wanted to know the answer too. Another participant said he was uncomfortable without an answer. He does not know what the prioritization process looks like for this area. Is the process part of the JFO or long-term recovery? Another said that in this scenario, it would still be the JFO, though response-oriented, because some anthrax cases are still being seen. 
At a transition point in the conversation, the moderator laid out a scenario. Lots of facilities are out of use. What needs to be done first? What happens? If it boils up from the local to the state to the federal level, the locals should be starting the process. What is that process? It is difficult to be effective at the local level unless the structure is understood. How can the local level get information without having a person sitting in the JFO? Some participants believed the only way for the local level to provide and gain information is by having a physical presence in the JFO.

A moderator then asked where the local input would happen. How does this local prioritization come into the JFO? A local participant said right now it does not. That is the big question. How does this work under the Stafford Act? How is it reconciled in the JFO? A state representative wondered whether it was realistic for individual counties to have a presence in the JFO, suggesting that it might be better to conduct video teleconferences (VTCs) rather than having a physical presence.

A participant then asked how federal agencies connect with locals when the feds come in and start walking the streets with instrumentation. Do the feds walk in under their own structure and report back up their own structure and down to the JFO, to the state, and then to locals? Or do the feds work directly with locals and filter information the other way? An EPA representative said that, at three months, the EPA would be an integral part of the command level. Tactical decisions would be made under a unified command. A participant noted that all groups attending this workshop have a different perspective of a unified command, but have no idea what that really means.

Another participant noted that, in any event, there will be adapting. If locals are not legitimately located in the JFO, there will be challenges. If it is supposed to bubble up from the bottom, one participant was not sure it could happen.

The moderator asked whether locals in the affected area could be connected somehow to the JFO. The FEMA representative said connecting all agencies is always a challenge. The goal is a unified coordination effort, however it is extremely complex as work does not necessarily begin or end in that office. The state has a similar challenge in coordinating all agencies. In the end, it is not about where someone sits, but about making sure there is a unified command.

Another participant noted that having someone inside the JFO may also strap local groups who have limited staff. A VTC process may allow more communication without someone being physically present.

The FEMA representative noted that sometimes the way things will work cannot be planned. The goal is to work things out for each situation with all of the affected parties.

\section{Emergency Support Functions}

\section{ESF-14 - Long-Term Community Recovery}

Another participant asked about Emergency Support Function (ESF)-14's role (Long-Term Recovery). The FEMA representative responded that it is a function that supports state partners. It includes FEMA's normal implementation as well as working with insurance agencies, infrastructure development, and other support as needed.

Another participant asked whether ESF-14 was sufficient to handle the scenario given in this workshop. FEMA would likely build on the function to meet the needs of one or more governors. ESF-14 may not be able to solve all long-term issues, but it provides a mechanism for all the right players. For example, ESF-14 began the recovery effort in New Orleans, which has now moved into the hands of local agencies and their authorities. Hospitals are funded, 
for example, through Medicaid/Medicare. The decision to transition is not made at the JFO level. Much of the recovery is not through the National Response Framework. It is through the statutory authority of state and federal agencies. The federal agencies share information with the JFO, but implementation is at the state and local levels.

\section{ESF=8 - Public Health and Medical Services}

The representative from the U.S. Department of Health and Human Services (DHHS) said that all information would be reported through the Laboratory Response Network. DHHS owns ESF-8, and would therefore establish the necessary standards. With regard to communication within the federal government, when the Secretary activates ESF-8, the emergency management group is staffed and the operations center establishes communication with the National Operations Center and the State Operations Centers.

\section{Regional Coordination}

A participant noted that there needs to be a way to bring all information together, face-to-face if possible. Otherwise there will be efforts to circumvent each other. There is a need to get organized at a regional level to offer information. There is currently no process to agree on major issues. Political entities need to be organized so they speak with one voice.

A moderator noted that the program is looking at prioritization. What is considered? What is presented to elected officials? Prioritization will not work unless there is an organization to receive that information.

A state representative noted that the Chemical Stockpile Emergency Preparedness Program (CSEPP) process may be able to offer a focal point for decision-making. But participants were not familiar with the process so could not judge whether it would work. The model may be too narrow, as it works for one jurisdiction. At the senior level, the structure is likely to change with each election. At the operational level, the right people must get together, either face-to-face or via telecommunication. The dialog takes place at the EOC level - therefore requests for support will come first to the state EOC, which will address as many as possible.

\section{Military Role and Authority}

A participant asked about the role of DoD. There can be prioritization at the JFO level, but what role does the DoD play in changing those decisions to meet military needs? Will military needs trump local needs? The representative from Fort Lewis answered that a lot will depend on the national military strategy. The military cleanup will be an internal issue for them, and although it does not trump local needs, it is taken into consideration. The Defense Coordinating Officer (DCO) resides in the JFO and coordinates with them.

Another participant asked what would happen if it were decided that the Port of Seattle was the first priority for cleanup. Could the military come forward to advocate for the Port of Tacoma because it supports the military? Federal representatives indicated that the discussion would happen at a very high level, probably at the Homeland Security Council. For example, for the recent Gulf Coast response, the decisions about limited resources were made at very high levels. When senior-level officials are having such discussions, they all know what is at stake.

\section{Prioritization Process}

A participant commented that in the unified command, the federal government has limited but specific resources it can provide across the nation. How would the city or state come to the federal level? If there are insufficient resources, who decides how to allocate them? What is 
the process for allocation at the federal level? FEMA representatives said that these are political decisions. The question does not have an answer at this point. The basic framework of how to do business is that locals respond, and when their resources are exhausted, they go to the state. When state resources are exhausted, they go to mutual aid compacts. When those are exhausted, they go to the federal government. If there is a shortage of resources based on requirements, the adjudication process starts at the highest level with FEMA's national response coordination center. There is not a specific answer, and no single person makes that decision, however the governor, the counties, the federal agencies, and others would be involved. The multi-agency JFO will take all kinds of information from all levels to move the resources where they can be most effectively used. In the field, incident command posts will be managing resources.

A state representative commented that recent exercises have used the Multi-Agency Commission (MAC) group to make decisions under the ICS system. The mayors were brought together to reach consensus on how to allocate resources. But how does this work when it reaches across states? What is the mechanism?

One of the participants expressed a concern that at three months, the decision-making framework could fall apart and elected officials could start jumping in. How is that managed? Will CSEPP handle that? Executives are never going to sign a document to cede their authority in an emergency. They may run to the White House behind everyone's back. Unless there is formalized agreement, there needs to be a stop-gap measure to prevent this.

A state representative responded that the CSEPP process does not cede authorities. Do the resources go to the state? The state representatives explained that the state works with county and city executives to determine priorities. The state does not take local resources.

A city participant noted that transparency was key. There needs to be delineation as to how federal agencies will put leather on the streets of Seattle. As long as the plan is known, transparency can transcend issues. If it appears that federal agencies are making decisions behind closed doors, people are left to wonder. With transparency, the locals will know what to expect from the feds and the federal agencies will know what to expect from the locals.

\section{Re-Entry Decisions and Process}

The moderator asked what process would work for the counties with regard to determining when it is safe to re-enter. A local representative said it needs to be looked at from a contamination perspective. How is the decision made about how clean is clean? Does a county have the authority to say when something is clean? Without those good clarifications, there will be no decision-making and lots of finger pointing. Who has the authority to decide when to move between stages and what kind of input comes from the locals?

The FEMA person noted that it is not a question of how clean it is but when it is safe to re-enter. For the two most recent evacuations, it was a local, political decision supported by the federal government. But the local executive will want to know what the standard is to know how clean is clean. The EPA representative said there is currently a zero growth policy until the science is better. EPA will clean up and provide the data to the health department. In wide-scale events, EPA staff from around the country will come to help sample and clean. EPA operates under ESF-10 and supports other areas under mission assignments. When those assignments go away, EPA becomes a regulator under the Comprehensive Environmental Response, Compensation, and Liability Act or the Resource Conservation and Recovery Act. Where EPA works depends on the event. In this scenario, at three months out, EPA would be working out of JFO and Area Commands. 
An EPA representative noted that there will be disagreements about how clean is clean. For radiation/nuclear issues, there is a team that decides. Perhaps the same process should be available for chem/bio issues.

\section{Breadth of Involvement}

A port representative asked whether there is a process for knowing how wide to spread the net. For example, the ports in the Northwest supply the state of Alaska. Will Alaska have a seat at the table? All the grain in Eastern Washington comes through the grainery in Seattle to the world. How is it determined who sits at the table to make decisions?

The DHHS representative said that every locality will be provided with a model for the state to use in determining the area affected. DHHS staff will populate the model, which has a great deal of information about economic considerations. A participant followed up by asking whether the model has the opportunity to support enforceable decisions. The DHHS representative responded that if it is regarding quarantine, that is a government function. CDC has the authority to issue quarantine orders, but no power to enforce. This would be a USNG or law enforcement function.

An EPA representative noted that there is an EPA/DHS group looking at recovery and response. The plan is to get a group of experts together who can advise decision-makers on health, environmental, and economic issues. The group is presently called the National Policy Decision Support Team.

A state representative noted that the Washington Restoration Task Force has all kinds of expertise represented. The state EOC has representatives from the business community and a person for community outreach. The state recognizes the interdependencies, particularly with Alaska and Oregon. There have been regional discussions but they are in the early stages.

\section{Focus Area 2: Public Health and Medical Services}

\section{Summary}

Public health and medical services are very important to the recovery process. The main issues discussed at the workshop were:

- The importance of maintaining a healthy hospital system

- The need for a process to establish a consensus on when it is safe to re-enter, across all jurisdictions including the military.

The following further details the discussion, including questions posed by participants and moderators and answers provided by appropriate agency representatives.

\section{Solvency}

A public health representative reminded participants that local staff generally do not have the resources to sample and determine what laboratory results mean. They will need expert help to do that. The question on solvency is a big concern that is faced every day. At the end of the day, a hospital's bank book will look dry. Even if only 2 of the 19 hospitals in the area shut down because of an event, the long-term health impacts could be extreme. It's not about rebuilding walls, such as after a hurricane. What happens if the health infrastructure fails?

A FEMA representative noted that there were hospital failures in New Orleans, but then other hospitals that stepped in began to struggle. There was some federal support. No one wants to see important infrastructure fail. Another participant wondered how those decisions 
were made. The FEMA representative indicated that, in the case of New Orleans, they had a hospital system that spoke with a single voice. They went up through the state. It was not through the Stafford Act but through separate statutory authority. The money came down through enhanced reimbursement mechanisms.

\section{Life Safety}

A FEMA representative wondered about an earlier comment regarding whether life was the overriding concern. He had never heard that question in emergency response, only in DoD. Another participant noted that in the recovery phase there may come a time when the scientific community will not agree on the long-term hazard and the decision will become a political one. The public health official may get the decision dumped in his or her lap with pressure to open the area. It gets back to who makes the decision of how clean is clean.

From a firefighter perspective, once zones are set up for the sites of contamination, the response protocol will be based on those zones. The primary concern will not be citizens in that area, but the workers in those areas, who still break legs and require assistance. The number one concern is life safety. But if an area in the contaminated zone is burning and there is no potential life loss, that building will be allowed to burn rather than put firefighters at risk. The county and city will have to change their response models.

Another participant asked whether the first responder community has a responsibility when a hot or "warm" zone has been established and people move back into that area regardless of recommendations. Another participant pointed out that in the most recent event in Galveston, it was made clear that if the residents did not evacuate, they would be on their own. Emergency response personnel need to have protocols and protective equipment so they can help in rescues and exposures. Three months out, they would provide emergency medical services, including to other emergency responders such as law enforcement.

\section{Re-Entry}

One participant explained that "How clean is clean" is not the same question as "Is it safe to go back in." For example, in Galveston there were concerns about mold and toxic soup, but the things that killed people were car accidents and gun fights. Another participant stressed that the media and citizens will still want to know how clean is clean. Although there is a scientific medical answer, there is also the court of public opinion and these questions will need to be addressed. It will be critical to have a coordinated, concentrated public information campaign to explain to people what they need to know.

The moderator asked who would be at the table and who would make the call on how clean is clean. An EPA representative said it is a local call, and EPA would assist with information. In the national exercises TOPOFF 3 and 4, progress has been made on how this would happen. The Interagency Modeling and Atmospheric Assessment Center (IMAAC) would provide one answer to the local decision maker. A participant asked, in this scenario, if county and state officials all hear the same information, what happens if one jurisdiction says yes and another says no? What will the state do? Another participant explained that the local health officer, the governor, and CDC have the same authority to decide. The policy is to achieve consensus. The Public Health Rapid Assessment Team (PHRAT) would come in and help officials reach consensus. The state does this on a smaller scale in other areas, such as radiological programs. Another participant stressed that if consensus cannot be reached, the public needs to understand why.

A local participant asked if the federal government would live by the same decision for the area, for example, for a federal building. A federal representative replied that all employers must decide for their employees. The Department of Labor is in charge of worker safety. They may 
have their own standards, but those standards will be based on EPA's and CDC's standards. Another participant reminded everyone that if a mayor said yes and a federal agency said no for its employees, the federal action would undercut the local decision. The federal representatives indicated that there would be a discussion, as the federal agency would want to avoid conflict. The federal agencies cannot make a decision for the local population. Best practices should be that there would not be two standards on an issue.

The moderator pressed for a process. A federal representative said that EPA, CDC agencies, National Institutes of Health, DoD, and Department of Labor would advise the state or county executive with a Protective Action Recommendation. The governor, county executives, or mayors would then make the Protective Action Decision. The information then goes to the Joint Information Center (JIC), which is staffed by federal, state, and local representatives. A state representative reminded participants that the governor's emergency powers were amended by the last session of the state legislature. The Attorney General is looking at how that amendment specifically affects the powers, but it will most likely limit them.

\section{Military}

Next, the moderator asked about the military. They will take action to protect their mission, and those actions will be seen by the public, and will also put pressure on the locals to follow suit or explain the different standards. The military can make decisions that affect its people that public health cannot make.

A federal representative cautioned participants to remember that Madigan Hospital on Fort Lewis serves one million beds per year. It is difficult to distinguish military from public when it comes to supporting health care. Military public affairs and public health are very connected to the community and keep information lines open.

\section{Medication}

The DHHS representative mentioned that the scenario needs to address whether Strategic National Stockpile (SNS) medication is effective against anthrax. The moderator indicated that the assumption is that medication is effective. The pandemic flu plan describes the prioritization of medication. CDC has an expectation that all exposed staff would have medication within 48 hours. The postal system is one option for distribution of this medicine. Another option is medical kits in people's homes that would allow them to start taking that medication on direction from the government. Points of distribution would have to be staffed, most likely by local government personnel.

A participant asked how medications flow from the SNS. The state requests the medication from the federal government, on authority from the governor. The federal government provides the medication and the expertise to the state distribution center, who would then distribute it to local public health.

\section{Results from Community Resilience Workshops}

After concluding the first two focus area discussions, Steve Stein presented results from a set of August 2008 workshops on community resilience, which were held with private sector and private property owners on their requirements for recovery and restoration following a disaster. Under support from DTRA, PNNL conducted a literature review, invited key regional and national stakeholders, conducted baseline assessment interviews, and facilitated three workshops. The complete presentation is located in Appendix C-5. 
Participants represented the building community, including building owners, building service providers, and commercial and residential real estate managers; major Northwest industry, including Boeing, Safeco Insurance, Costco, Premera Blue Cross, United Grocers, Port of Seattle, and Unigard; and the service sector, including transit, railway, medical services, and power, sewer, and water providers. After hearing an overview of the IBRD program and a scenario involving anthrax, they discussed the major concerns regarding the ability to recover from a biological disaster and restore property and normal business operations. Then they prioritized these concerns and discussed what might be needed to address the top issues.

For private business, the top concerns involved lack of planning guidance, inconsistent messaging from multiple sources, confusion over how recovery priorities are set, limited remediation resources, and indemnification and liability issues. One of their greatest fears was that they would hear conflicting messages from federal, state, and local agencies. They wanted a single message from a credible source, most likely the CDC. Industry's perspective is that they will be responsible for cleaning up their own facilities, and they will be aggressive about it. Therefore, the competition for scarce resources could be stiff.

Large building owners and managers had different concerns. They also felt they would be responsible for cleaning up their own facilities. They wanted requirements and guidance from the federal government on how to restore and how to train staff to restore facilities. They felt there was a six-month window; if lessors cannot occupy a space for six months, they lose a tenant. If cleanup cannot occur quickly enough, they will walk away from the buildings.

When it came to service providers, participants felt the local public health organization would be a credible spokesperson. Their key concerns were communications, assuring worker safety, allaying fears, and command and control.

The most significant conclusion from these workshops is that communication is critical. Information must come from a credible source, with one message. Two-way communication must occur between the private sector and command and control. Another important conclusion is that prioritization of recovery and restoration activities needs to be better understood and informed by private sector needs. In addition, the private sector needs education and resources on anthrax/ biological incident restoration that enables them to make and act on decisions.

\section{Focus Area 3: Community Resiliency and Continuity of Government}

\section{Summary}

Community resiliency and continuity of government have come up in several discussions at past program events. The main issues discussed during this workshop were:

- Insurance coverage for both private businesses and individuals

- Response plan coordination

- Interaction between the government and industry.

The following further details the discussion, including questions posed by participants and moderators and answers provided by appropriate agency representatives. 


\section{Private Sector Resources}

\section{Insurance Coverage}

The representative from the State Insurance Commissioner's Office noted that laws changed in 2007 to allow insurance to include non-foreign terrorists and biological attacks. To be eligible for coverage, the act must be done with the intent of intimidating or coercing the citizens. Given the scope of the scenario, private sector companies with terrorism insurance would be covered for cleanup. However, the coverage does not include loss of business revenue. Businesses without this coverage will have no resources to assist with cleanup costs. The state representative cautioned participants to remember that insurance is a contract.

The moderator then asked about terrorism as an act of war and how that is defined. The state representative replied that if it meets the definition of a terrorist event, it is considered a terrorist event. How fast the payment occurs will depend on what needs to be done to remediate. If the insurance company can estimate costs, the money can come in quickly. There does not seem to be consensus on what remediation entails for anthrax, so it is more difficult in that situation. Once the money comes in, it's up to the homeowner to choose a contractor and remediate.

A FEMA representative indicated that FEMA does not offer assistance until after insurance responds. FEMA does not respond to private property owners directly. However, they can help coordinate and facilitate.

\section{Response/Recovery Plans}

A participant noted that response plans differ across businesses. Larger businesses may be robust, but smaller ones may not have thought through the issues. Can insurance provide an incentive for businesses to be consistent? Another participant replied that it is an incentive for larger businesses to get and maintain policies, but not for smaller businesses. There is no oversight. Insurance might be able to offer rebates or reductions, if they choose. The Insurance Commissioner is working with Health Maintenance Organizations and Preferred Provider Organizations to encourage them, and get them to encourage their customers, to have business continuity plans. A local representative noted that a small business owner's disaster resiliency toolkit is coming out through King County or Seattle. The City of Bellevue has talked to a local insurance carrier to develop a business continuity plan for small business, perhaps with some rebate offered in the future.

\section{Government Interaction}

A participant asked where the interface was for industry in the region during the recovery and restoration process. How is the JFO updated on industry actions? A state representative indicated that the state has started to enter into agreements with big box entities. Locals would then no longer be responsible for doing that. The ports are also part of the state emergency management process. Pierce County has a person on the EOC that represents industry. They have been told that industry will make decisions about what to do based on what actions they see from the government. The EOC can also offer information to industry. Where the interface is located and how it functions depends on the government organization. If the state takes care of the large chains, it is easier for the locals to work with other members of industry.

A moderator noted that the scenario has 500 buildings contaminated. A large portion will be private-sector buildings. Big business will move quickly to characterize and remediate the problem. Providing them information and training (growing a workforce) may lead to head-to-head competition for resources. Is there a decision process there?

In response, a participant explained that lots of big businesses have pre-existing contracts 
for disaster assistance. The government may have to go in and take those resources for the common good. Is there an approved protocol in the EPA process for characterization and remediation contractors? An EPA representative indicated that currently there is no such process, but noted that the EPA National Decontamination Team is currently developing procedures.

Another participant wondered whether there were different plans for critical service providers and other businesses when it comes to prioritizing resources. A local representative replied that counties are identifying critical infrastructure, per DHS guidelines, and are putting contracts in place to keep government operating. Keeping a private entity in business is not the government's job. The government's role is to provide the infrastructure so they can be in business. Industry needs to understand that restoring critical infrastructure is the first priority. Another participant cautioned that business, government, and first response agencies form the community and must work together.

\section{Citizens - Insurance Coverage}

Most homeowners do not have terrorism coverage and nearly every policy has exclusions for acts of war, even if not declared.

Health care providers may have a more generous outlook. The State Insurance Commissioner would rule that displaced persons would still be covered by healthcare, to some degree, even if outside their network.

\section{Next Steps}

Participants agreed on the following next steps from the workshop:

- Hold a workshop to make sure that all local jurisdictions and state agencies share a common definition of the unified command and area command structures. FEMA offered Pat Massey for Region 10 as the federal agency representative point of contact. He is working with the states to develop a conduct of operations for Region $E$ for pandemic and chemical/biological events.

- Create a local collective process for developing a unified voice and setting priorities for the emergency management community, working with Sandia National Laboratory as appropriate.

- Update and modify the recovery organizational chart, perhaps after the November 2008 election.

- Ask state officials to get back to this group about how the governor's emergency powers have changed.

- Prepare a summary report and provide to all attendees. 


\section{Appendices}




\section{Appendix A - Acronyms}

CDC

CBRNE

CSEPP

DCO

DHHS

DHS

DoD

DTRA

EMMRI

EOC

EPA

ESF

FCO

FEMA

$\mathrm{HHS}$

IBRD

IMAAC

JIC

JFO

JTF

ICS

OHA

PFO

PHRAT

PNNL

SFLEO

SNS

TOPOFF

USCG
Centers for Disease Control and Prevention

Chemical, biological, radiation, nuclear, and explosives

Chemical Stockpile Emergency Preparedness Program

Defense Coordinating Officer

U.S. Department of Health and Human Services

U.S. Department of Homeland Security

U.S. Department of Defense

Defense Threat Reduction Agency

Emergency Management and Medical Response Integration

Emergency Operations Center

Environmental Protection Agency

Emergency Support Function

Federal Coordinating Officer

Federal Emergency Management Agency

Department of Health and Human Services

Interagency Biological Restoration Demonstration

Interagency Modeling and Atmospheric Assessment Ceter

Joint Information Center

Joint Field Office

Joint Task Force

Incident Command Structure

Office of Health Affairs

Principal Federal Official

Public Healt Rapid Assessment Team

Pacific Northwest National Laboratory

Senior Federal Law Enforcement Official

Strategic National Stockpile

Top Officials

U.S. Coast Guard 


\title{
Appendix B - Agenda
}

\author{
Addressing the Federal-State-Local Interface \\ Issues during a Catastrophic Event such as an Anthrax Attack \\ Washington State Convention and Trade Center - Room 3AB \\ 800 Convention Place, Seattle, WA
}

October 9, 2008

8:00 a.m. to 4:00 p.m.

Sponsored by the Interagency Biological Restoration Demonstration (IBRD) Project Jointly sponsored by Department of Defense and Department of Homeland Security

8:00 Continental Breakfast and Registration

9:00 Opening Remarks

9:15 Welcome by Local Emergency Management

\section{9:20 DHS Remarks}

\section{9:25 IBRD Overview}

\section{9:30 High Level Scenario Overview}

9:40 Principal Federal Official Comments

\section{0:15 Break}

10:30 Review of Pre-Event Information Gathering

- Uncertainties, gaps, points of conflict

- Recovery focused

- Initial ConOps

10:45 Focus Area 1: Decision-Making, Prioritization and Command and Control

\section{2:00 Working Lunch}

Ann Lesperance

Pacific Northwest National Laboratory

Steve Bailey

Director, Pierce Co. Emergency Management

CAPT Julie Sadovich RN PhD

Director, EMMRI

Office of Health Affairs, DHS

Ryan Madden

Department of Defense

Steve Stein

Pacific Northwest National Laboratory

RADM John Currier, USCG

Principal Federal Official

Steve Stein

Steve Stein and Mike Midgley 
1:00 Focus Area 2: Public Health and Medical Services

- Continuous health monitoring

- Sustaining medical system

2:15 Break

2:30 Results from Community Resilience Workshop

2:40: Focus Area 3: Community Resiliency and Continuity of Government

- Federal Financial Support

3:30 Next Steps and Wrap Up
Steve Stein and Mike Midgley

Steve Stein

Steve Stein and Mike Midgley 


\section{Appendix C - Presentations}

\section{C-1 IBRD Overview}

\section{Program Overview}

- Goal: Reduce the time and resources necessary to recover and restore wide urban areas, Military Installations, and critical infrastructure following a biological incident

\section{- Objectives}

- Understand the social, economic, and operational interdependencies, past and present, that impact recovery and restoration actions

- Establish long term formal coordination between DoD and DHS and how this level of coordination can be optimized for stakeholder's use at the state, regional, and local levels

- Develop strategic restoration plans for DoD \& DHS that can be utilized in other parts of the nation

- Identify \& demonstrate technologies that support recovery and restoration operations

- Exercise restoration activities \& available technology solutions using national planning scenarios

DoD (DTRA-JSTO) \& DHS (S\&T) co-sponsored program 


\section{C-2 Scenario}

\section{Workshop Rules of Engagement}

- Don't Fight the Scenario._The scenario is simply a tool designed to stimulate discussion. Assume the scenario is plausible and events occur as presented.

- Don't "game" the game. The Workshop scenario is not a win/lose situation.

- Share your knowledge and experience. Do not assume that other participants know all about your organization and how it does business.

- Understand that the Facilitators have to keep the discussions moving along. We will record issues that should be explored in more detail in other venues.

- Remember this Workshop is about RECOVERY

\section{Initial Response}

The attack in downtown Seattle, Pierce County surrounding areas, and on the Fort Lewis Army installation originally occurred in early July, when a few non-descript trucks released aerosolized anthrax while driving through the downtown Seattle core, and hours later, near the Fort Lewis military base. Sick people began showing up in emergency rooms, and Biowatch confirmed that anthrax had been released. The population panicked and self evacuated. Fort Lewis locked down, limiting access to essential personnel. Hundreds of thousands of people were exposed and required immediate medical treatment. Public health officials requested push packages from the Strategic National Stockpile (SNS). After a few days, the Seattle areas around Fort Lewis remained quiet; people outside the heavily contaminated areas generally obeyed shelter-in-place orders. Although prophylaxis (vaccine and antibiotics) did occur from the SNS, thousands of people perished and thousands remain seriously ill. Law enforcement worked to maintain civil order. No additional attacks were seen in the country, and the Federal Bureau of Investigation (FBI) has been throwing all of its resources at these two events. Area hospitals were in surge mode and overwhelmed with a combination of sick and worried well. The initial hot zone control was established, employing National Guard and law enforcement. The Joint Field Office (JFO) has been set up, as has the State Recovery Task Force. Area Command structures have been established in both Seattle and Pierce County. Fort Lewis is in command of response activities on base. 


\section{Three Months after the Attack}

Seattle: Today, at 3 months after the attack, several square miles of the downtown core of Seattle are contaminated with anthrax. While decontamination is occurring in some buildings, most remain empty. The sense of panic has subsided as the streets are abandoned with the exception of emergency and cleanup crews. Many transportation corridors have been closed, and traffic is moving through defined areas. Seattle City government and King County government have been reconstituted elsewhere in King County. Basic services are running at a minimal levels, including emergency management services (EMS), a limited number of hospitals, utilities, law enforcement, and other essential services. The Port of Seattle is in limited operations. Trucks departing the Port go through the Metro bus wash as a precaution and to provide confidence to others that shipments are not contaminated. Metro buses are moving on limited routes around the contaminated zone in the city. Area Command has transitioned from response to recovery and is being supported by Seattle and King County Emergency Operations.

Fort Lewis/Pierce County: Fort Lewis is restricted to essential personnel only. Facilities on base and businesses, homes, and rentals within a one-mile radius surrounding the base are all confirmed or suspected to be contaminated. The military has initiated decontamination and cleanup operations on base. For a time, waste begins to pile up on site until decisions can be made regarding disposal of waste potentially containing anthrax. The I-5 corridor was temporarily closed during response, but has since been reopened.

In General: The vast majority of people living and working in Seattle and surrounding Fort Lewis have self evacuated but will need placement and financial assistance in short order. Some $\mathbf{7 5 , 0 0 0}$ to 100,000 others have no means to leave and will need assistance and support. Hospitals and major medical facilities on the fringe of the contamination zone are financially strapped and struggling to survive. Continuous cases of anthrax are reported. Schools in the city area are closed; schools further out are on limited or full operations. Basic goods are being supplied, but the flow is more difficult. Officials have agreed to an overarching strategy to try to "knock down" external contamination by flushing with water before performing more rigorous decontamination procedures. After that, decontamination efforts would generally be focused at the outer perimeter of the contaminated area, pushing cleanup toward the center, or most contaminated portions of the city. Some private building owners have initiated clean up of their own facilities, which has resulted in significant volumes of waste. In addition, garbage has been piling up in the city awaiting decisions regarding disposal of anthrax-contaminated waste. Questions regarding "how safe is safe" and "how clean is clean" are being debated but are not resolved. 


\section{U. S. Federal Response to a Pandemic or Major Bio-Threat Incident}

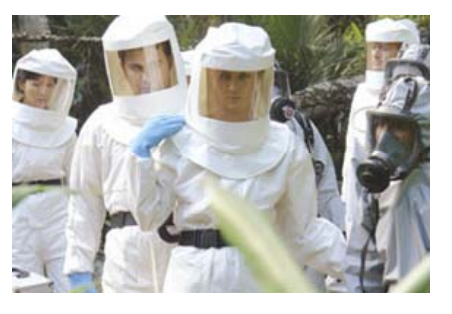

RADM John Currier Region E - PFO 9 October 2008

\section{Department of Homeland} Security (DHS)

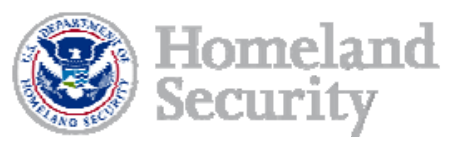

How the $U_{1} \Theta_{s}$ Governmment will react 


\section{Homeland Security Act of 2002}

- Homeland Security Act of 2002: the Secretary leads DHS in executing its key missions:

- Preventing terrorist attacks

- Reducing the country's vulnerability to terrorism

- Minimizing the damage and assisting in recovery from terrorist attacks that do occur in the U.S.

- Acting as a focal point regarding natural and manmade crises and emergency planning

- The Secretary's role as defined in the Homeland Security Act is further refined in Homeland Security Presidential Directive - 5

\section{Homeland Security Presidential Directive (HSPD) - 5}

- The Secretary of Homeland Security is the Principal

Federal Official for domestic incident management

- The Secretary:

- is "responsible for coordinating Federal operations within the United States to prepare for, respond to and recover from terrorist attacks, major disasters, and other emergencies"

- "shall coordinate the Federal government's resources utilized in response to or recovery from terrorist attacks, major disasters, or other emergencies" 


\section{National Response Framework: Principal Federal Official}

- Serve as Secretary's direct regional representative

- Conditions when a PFO may be designated:

- For catastrophic or unusually complex incidents requiring extraordinary coordination;

- In instances in which FEMA should not be the lead agency, such as a pandemic outbreak;

- Major non-Stafford Act responses occur even though the response may include a Stafford Act component;

- PFO interfaces with Federal, State, tribal and local jurisdictional officials on overall Federal incident management strategy;

- Serves as primary point of contact and situational awareness for the Homeland Security Secretary

- Provides a coordinating and deconfliction function for the Secretary

\section{National Guidance \& Authority for Pandemic Influenza (PI)}

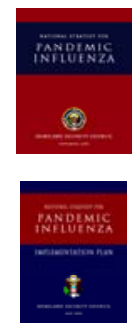

National Strategy - President Signed November 2005

Establishes 3 pillars

- Preparedness and Communication

- Surveillance and Detection

- Response and Containment

National Implementation Plan - May 2006

Department of Homeland Security

FEMA (Stafford Act)

ICE, CBP, TSA, USCG

Department of Health and Human Services

Department of State

Department of Defense

NORTHCOM

Department of Education

Department of Commerce

Department of Transportation 

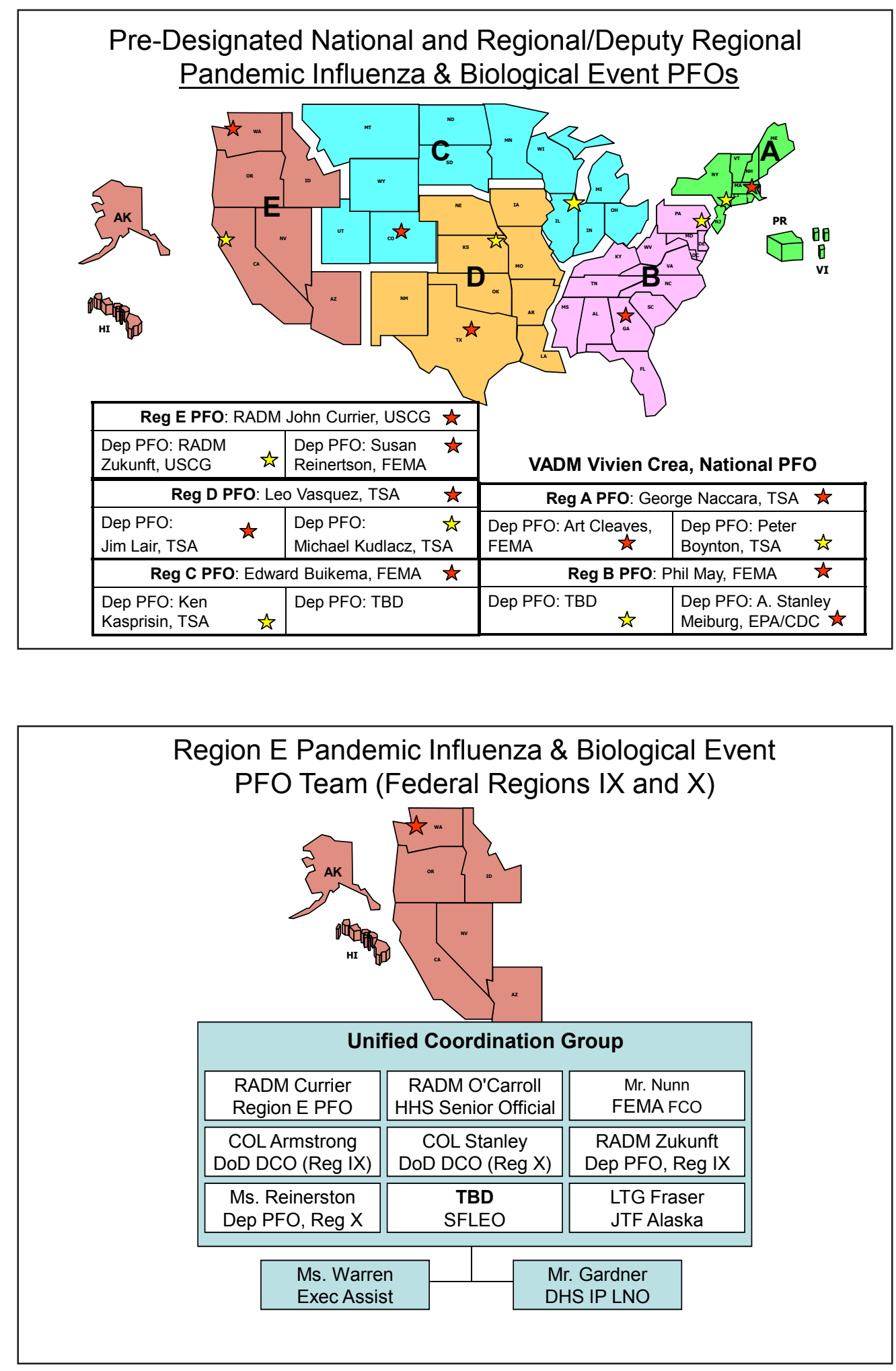

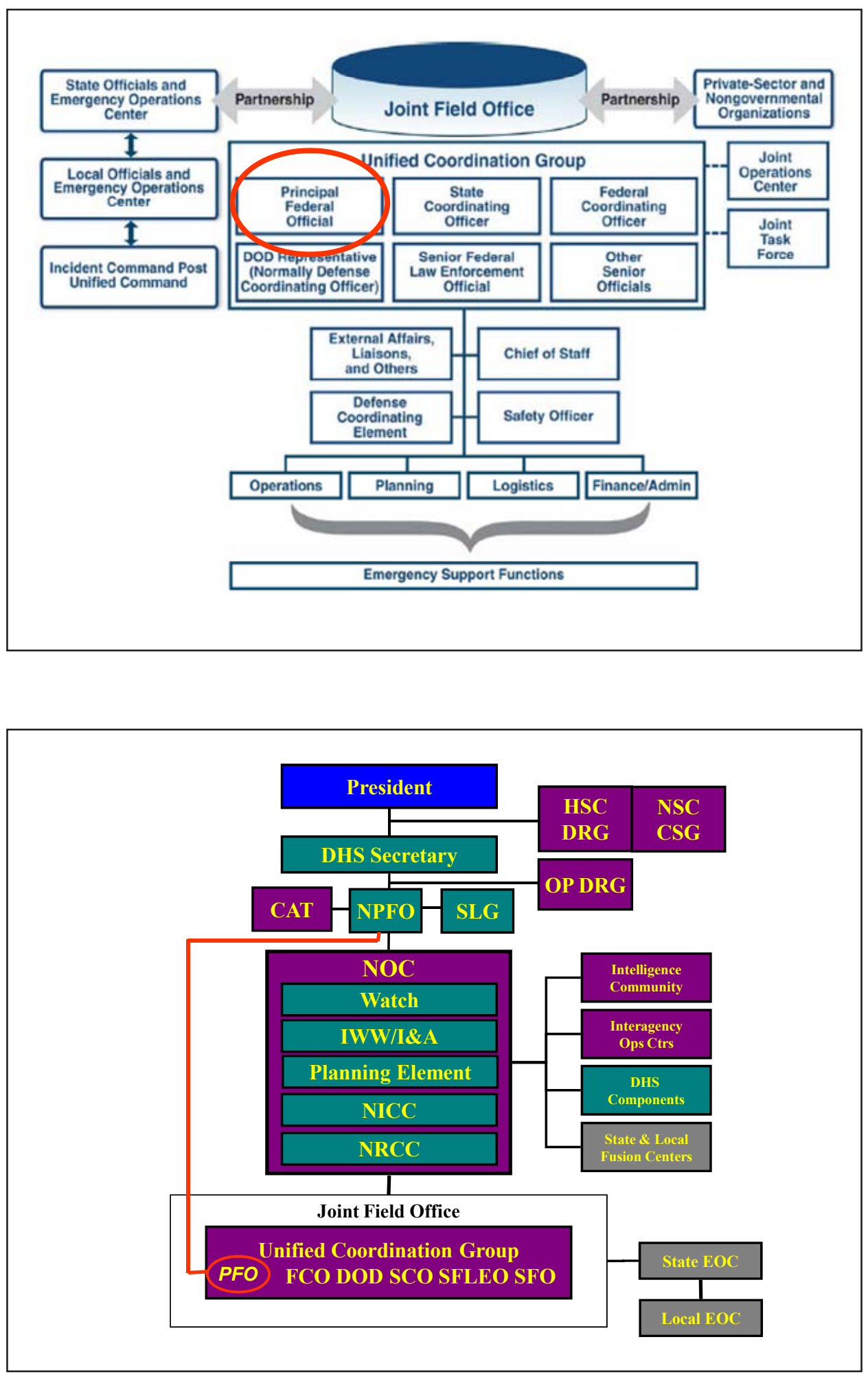


\section{Conclusions}

- Need for effective and integrated policies

- Executable

- Strategic communications plan

- Alignment

- Synchronized (Multiple Interests, Vertically \& Horizontally)

- Credibility

- Effective decision process

- Clarifying process how issues should be resolved

- The department/agency with legal authority to make the decisions

- Integration of Federal Department/agencies with state/territorial/local/tribal/private sector/NGOs

- Exercise, Exercise, Exercise 


\section{C-4 Pre-Event Information Gathering}

\section{Pre-Workshop Interviews}

Interviews were held with local, state, and federal emergency management staff.

a Locals

- Emergency management (King County, Pierce County, Snohomish County, City of Seattle)

- Public health (King County, Pierce County)

State

- EMD

Federal

- FEMA Region 10

- EPA Region 10
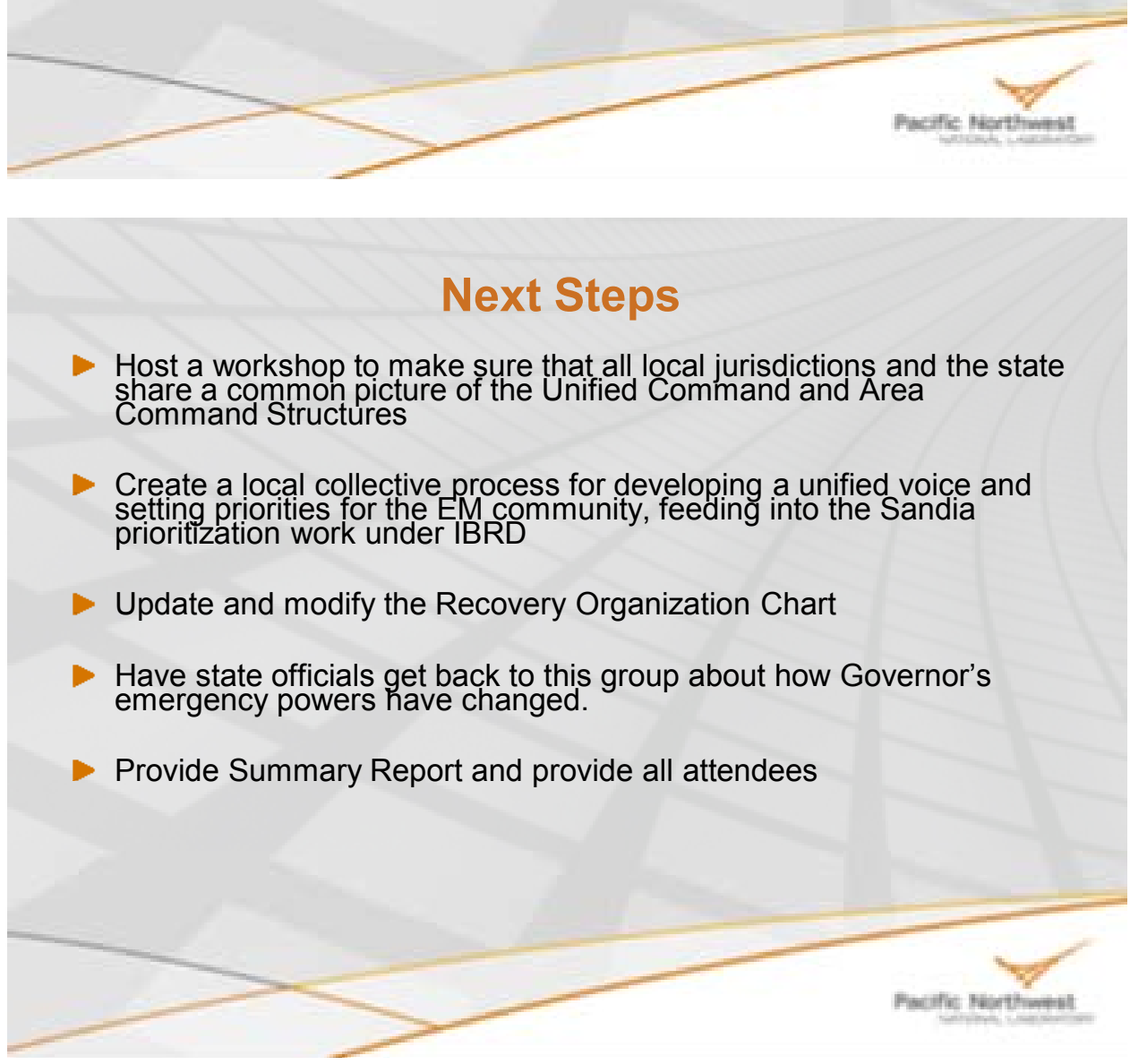


\section{C-5 Community Resilience}

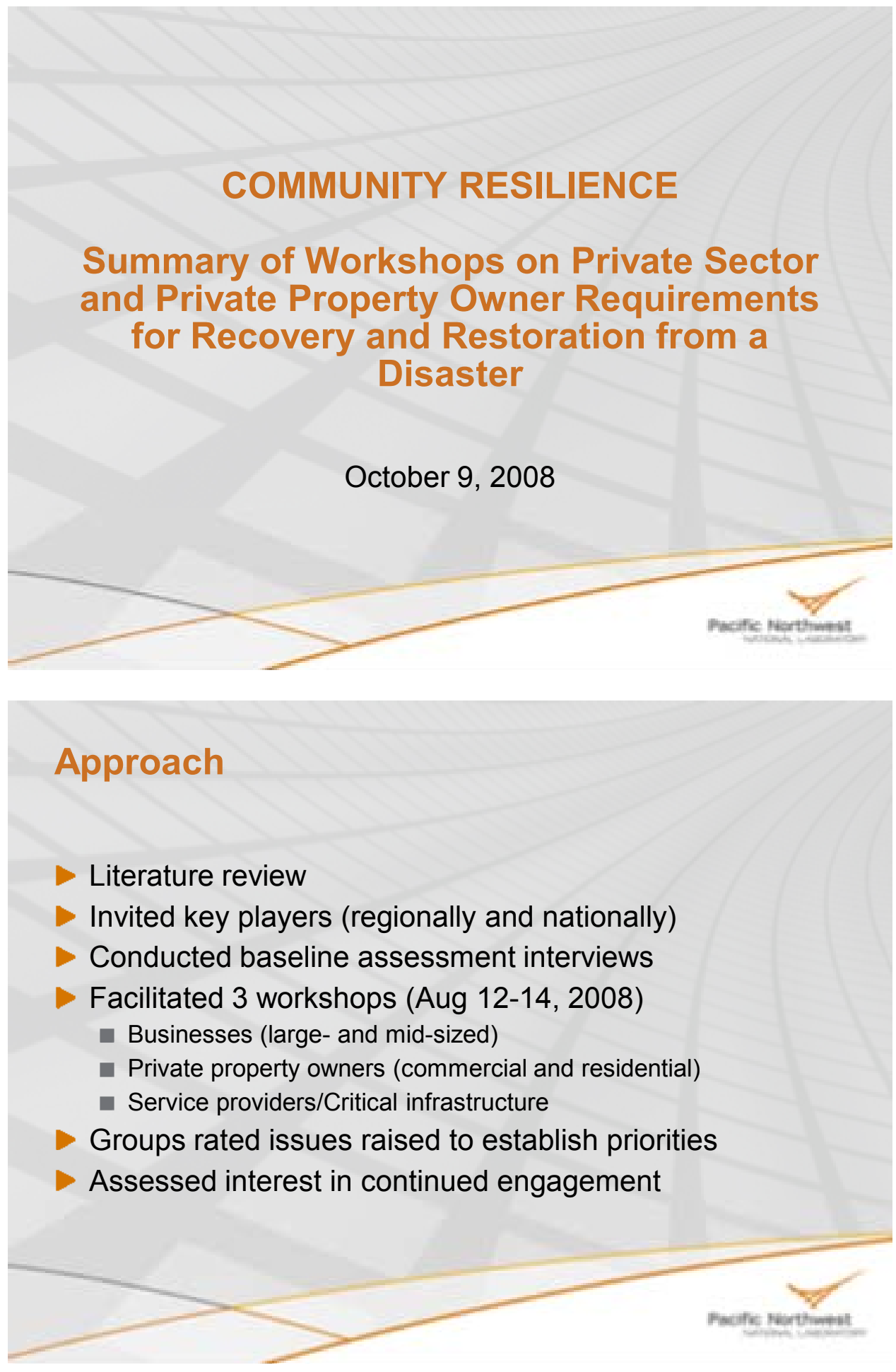




\section{Objectives of Private Sector Workshops}

Key Question: What is the ability of private sector businesses, building owners, service providers to restore property and recover business operations in the aftermath of a wide area dispersal of anthrax?

Assess private sector readiness to restore property and recover business operations

- Understand what businesses and private property owners "want and need" from federal, state and local government to support recovery and restoration from a disaster

- Use information shared during the workshops to support the development of guidance or other resources identified as high priority to enhance the ability of the private sector to recover and restore operations after such a disaster

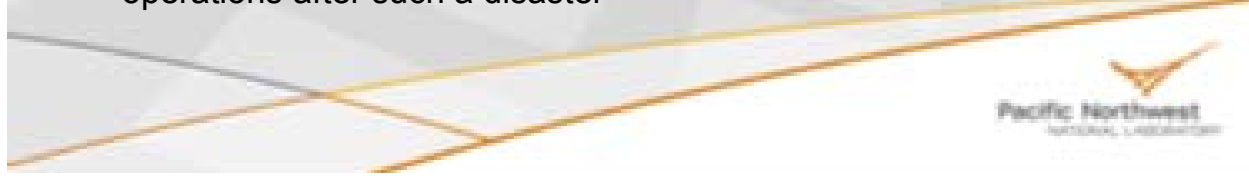

\section{Objectives of Private Sector Workshops}

Key Question: What is the ability of private sector businesses, building owners, service providers to restore property and recover business operations in the aftermath of a wide area dispersal of anthrax?

- Assess private sector readiness to restore property and recover business operations

- Understand what businesses and private property owners "want and need" from federal, state and local government to support recovery and restoration from a disaster

- Use information shared during the workshops to support the development of guidance or other resources identified as high priority to enhance the ability of the private sector to recover and restore operations after such a disaster






\section{Key Findings from Workshops Building Owners and Managers}

Participants: Able, ABM, Beacon Capitol Partners, CBRE, CAC Real Estate Management, Tishman Speyer, Institute of Real Estate Management, McKinstry, Metzler Realty, Wright Rundstad, Washington Real Estate Holdings, The Ashforth Companies, Building Owners and Managers Association (BOMA) of Seattle and King County, Rental Housing Association of Puget Sound

\section{Top Concerns}

1. Knowledge about anthrax remediation (e.g. protocols, technologies, service providers)

2. Actionable and two-way communications from credible source (e.g. CDC)

3. General anthrax education

4. Financial viability and support/incentives

E Asset reimbursement - Terrorism Risk Insurance Act covers only acts of foreign terrorism

- Access to low-cost loans and loan deferrals; difficulty paying mortgages without rental income

- Relocation assistance to keep it local

5. Uncertainty about prioritization of infrastructure restoration

- Would homes, critical infrastructure, businesses come first?

- Timely cleanup is critical to decision to stay or relocate

- Commercial building owners likely to walk away in $\sim 6$ months

- Residential owners have $\sim 2$ months or people will not return to the building

\section{Key Findings from Workshops (cont) Building Owners and Managers}

\section{Other Issues/Needs}

- Toolkit for facility planning for a biological event for integration into existing plans

c basic health information

- anthrax response and remediation information

I remediation service vendors

- key government contacts

- risk management planning

- Indemnification - need federal backing to limit liability if tenants return 


\section{Key Findings from Workshops Critical Service Providers}

Participants: Harborview Medical Center, Virginia Mason Medical, Tacoma Power, Puget Sound Energy, Seattle City Light, Seattle Public Utilities, King Co. Metro Transit, WA State DOT

\section{Top Concerns}

1. Communications

- From trusted, credible source (e.g. local health office)

E 2-way with private sector to ensure their priorities are understood

- Media must be a partner to ensure consistent messaging

- Public education to manage fear

2. Assuring Worker Safety and Allaying Fears

- Education on treatment, risks, and safety

- Rapid healthcare response is key

3. Command and Control

I. Who is in charge?

- How transition from response to recover?

- How recovery and restoration prioritization decisions made?

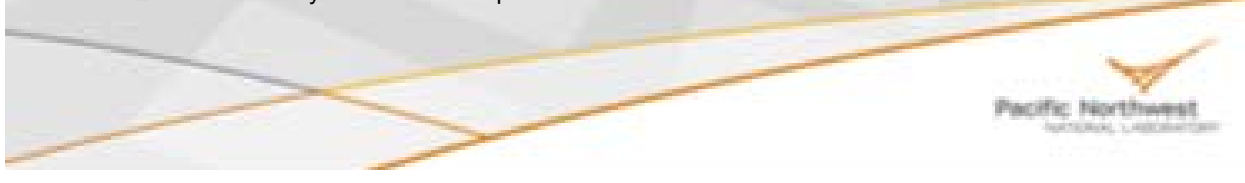

\section{Key Findings from Workshops Critical Service Providers}

\section{Other Concerns/Needs}

Transportation

- Opening key transportation corridors critical, ensuring clean routes not re-contaminated

E. Decontamination of vehicles (public transit, trucks)

- Understand interdependencies

- Critical businesses may not have continuity plans

- Government needs to consider supply chain in recovery

Legal and regulatory - may nee permit or liability waivers on case-by-case basis

- Essential supplies and services

I Pre-determined system to identify these (utilities, water, solid waste management, food, fuel )

I. Plan for getting these services to those in need

- Expand cleanup resources and capabilities

Establish protocols

- Provide training

- Pre-certification of key people (e.g. building inspectors, truck drivers)

a Credentialing essential workers

E Leveraging citizen corps

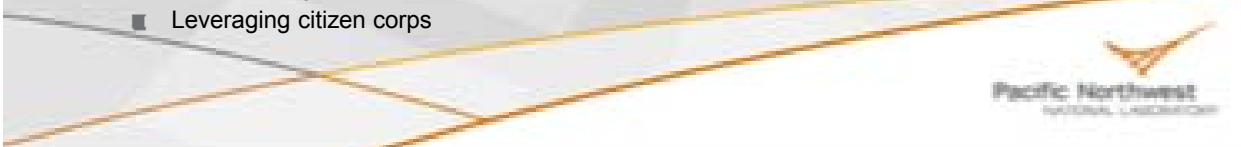




\section{Conclusions}

Communications is key to private sector R\&R

- Must come from a trusted, credible source; for many, CDC a credible voice in a biological incident

- One message

- Two-way between private sector to command and control

Prioritization of R\&R activities needs to better understood and informed by private sector needs

- Uncertainty about how decisions would be made

- Time critical to stay or go decision

- Need quick, clear direction from government on non-occupancy

- Need for education and resources on anthrax/bio incident restoration that enable businesses to make decisions and act

Indemnification and legal liability issues a concern to all

- Financial support to support R\&R a key concern for small businesses and building owners

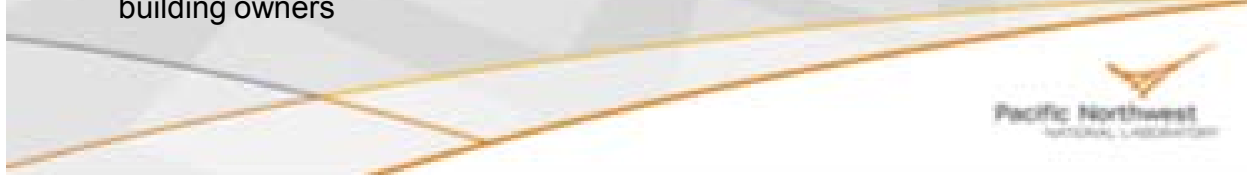

\section{Community Resilience Discussion}

- Insurance Contract Issues - "Terrorism" vs Acts of War. Coverage various challenges (health care policies more generous than property). FEMA support issues. Business Continuity Plans should be used as an incentive for policies? Need to enhance ability to develop good plans. Some efforts underway (e.g. City of Bellevue).

Industry Interface - how to provide feedback to command structures? State is addressing to some extent with regional businesses. Will occur within EOCs

- Protocols for Remediation - None yet (EPA). Development of techniques in process.

- Regional Government $\mathrm{Cl} / \mathrm{KR}$ Plans - in process but the key here is for business to understand the gov't role is to provide essential services (water, power, trans). They must assume responsibility for continuity of businesses. Current list is not unreasonable but can easily become so. Need to have balance between providing support and business providing own support.

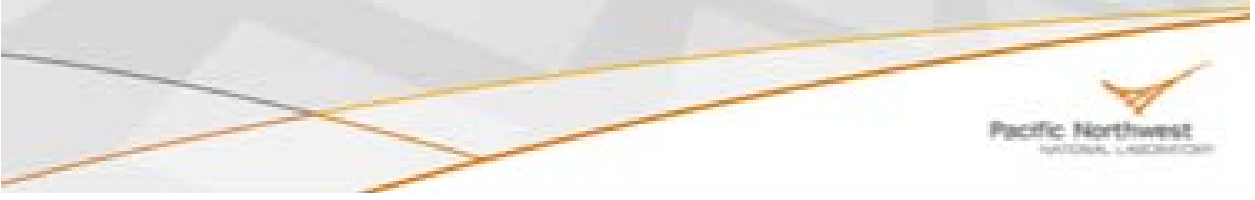




\title{
Appendix D - Pre-Event Information Gathering
}

\author{
Workshop Interview Protocol \\ Addressing the Federal-State-Local Interface Issues \\ during a Catastrophic Event Such as an Anthrax Attack
}

Name:

Title:

Organization:

Telephone:

Email:

\section{Workshop Objective:}

- Clarify and share information regarding the federal government's role during a catastrophic event, such as a large-scale anthrax attack.

- Further define/refine the role and actions of federal agencies that will be involved in recovery efforts; further define/understand the command and control relationships between federal, state, and local organizations; and begin the development of a concept of operations [process flow diagram] that will illustrate the relationships, decision framework, and resources of the local, state, and federal agencies.

\section{Scenario and associated assumptions}

To add

\section{Questions:}

\section{Decision-Making and Prioritization and Command \& Control}

\section{Decision-Making:}

- What are your biggest concerns, uncertainties, and points of conflict with regard to decision-making?

- How would this occur in recovery? Players and roles?

- Would this change over time?

- Is it understood how area or unified command would be established? Are there any gaps in understanding how the feds would support command and control?

- Are there clear roles of the various government agencies in decision making?

- Are there any gaps with respect to messaging? Does that change in long-term recovery?

- What is the main issue you would like to see addressed at the workshop with respect to decision-making?

\section{Prioritization:}

- What are your biggest concerns, uncertainties, points of conflict with respect to prioritization?

- Is there a clear process as to who is responsible for prioritization of buildings?

- Does this change when looking at public versus private buildings? 
- How would the prioritization for remediation of buildings occur? Are the federal, state, and local roles understood?

- Who pays and what do they pay?

- What is the private vs. public role?

- Who issues the certificate of occupancy? What are the criteria?

- Who issues the certificate of use?

- Is it clear how remediation and restoration priorities would be established? Are there any gaps with respect to the role of each of the federal agencies (nationally and locally)? If so, what are they?

- What is the main issue you would like to see addressed at the workshop with respect to prioritization?

\section{Command and Control:}

- What are your biggest concerns, uncertainties, and points of conflict with respect to command and control?

- How would command and control change with respect to recovery? One week later? One month later? Six months later?

- What is the main issue you would like to see addressed at the workshop with respect to command and control?

- Are the feds in control of anything? What are they in charge of?

- What are the basic services that need to be maintained to enable restoration and recovery?

\section{Public Health/Medical Services}

- How would you ensure solvency of public health and medical services?

- Medical system impacts -impacts on hospitals, clinics, private doctors, long-term care, nursing homes, group homes, correctional institutions, dental, pharmacies, mental health, EMS

- How do we build capacity?

- How do we replace (rebuild) capacity? Or not?

- What are licensing issues?

- How would patients be transported out of region/state? Who is responsible?

- Resource capabilities and capacity

- Human resources, healthcare equipment and supplies, medical services, lab, support (food, housing, etc.)

- Pre-identification of state and federal resources (includes military)

- Prioritization of available of resources

- Long-term monitoring/patient tracking

- Who does this? Ten years out?

- Are there gaps or conflicts with respect to national-state-local policy issues?

- Vaccine efficacy

- Medicare/medicaid payment, rules

- Making antibiotics over-the-counter medicine (Food and Drug Administration)

- Guidance; Stafford act verification; what's covered and not?

- How do we make vaccines available over the counter?

- How can people get access to health care? Who is responsible? 
- What is the main issue you would like to see addressed at the workshop with respect to public health and medical services?

\section{Community Resiliency/Continuity of Government}

- What resources do the feds bring?

- Funding

- People

- Equipment

- Compensation (Stafford vs. declaration of war)?

- How would continuity of government operations be ensured? How does this change one month out? One year out?

- How would continuity of operations occur (i.e., assume lost tax base of the businesses that move out of the area)?

- How would you ensure solvency of businesses (i.e., private sector and critical infrastructure)?

- Is there a government responsibility to clean up a city?

- What does FEMA pay for? What don't they pay for?

- What is government's responsibility for privately owned buildings?

- What will insurance cover? What won't it cover?

- What is the main issue you would like to see addressed at the workshop with respect to community resiliency? 


\section{Appendix E - References on Anthrax}

\section{罚IDSA}

Anthrax: Current, comprehensive information on pathogenesis, microbiology, epidemiology, diagnosis, treatment, and prophylaxis Last updated March 9, 2008.

This well organized 93 page document includes 23 pages of references and can be found on a free public website at http://www.idsociety.org/ under the bioterrorism section. This biodefense material is provided by a collaboration between IDSA and the Center for Infectious Disease Research and Policy at the University of Minnesota with funding from the Centers for Disease Control and Prevention (CDC). The direct link is: http://www.cidrap.umn.edu/idsa/bt/anthrax/ biofacts/anthraxfactsheet.html

The CIDRAP (http://www.cidrap.umn.edu) mission is to prevent illness and death from infectious diseases through epidemiologic research and the rapid translation of scientific information into real-world practical applications and solutions. They conduct critical review and analysis of available scientific and public policy information on selected topics and generate authoritative, accurate, and current web-based content accessible to all at no cost. Complete and comprehensive assessments are posted for avian/pandemic influenza, anthrax, botulism, plague, smallpox, tularemia and viral hemorrhagic fevers.

Ursano RJ, Norwood AE, Fullerton CS. Bioterrorism, Psychological and Public Health Interventions. Cambridge England: Cambridge University Press; 2004.

This comprehensive 360-page text has specific chapters on differentiating infection from psychiatric disorders, biopsychosocial factors, children, social support, first responders, strategies for preparedness response and recovery, legal issues, and communication.

\section{Additional References}

Malone JD. Pre-event smallpox vaccination for healthcare workers revisited - the need for a carefully screened multidisciplinary cadre. International Journal Infectious Disease 2007;11:93-97.

Malone JD. Provider and health care system response to a bioterrorist attack. Baylor University Medical Center Proceedings 2001;14:224-30.

Nemeroff CB, Bremner JD, Foa EB, Mayberg HS, North CS, Stein MB. Posttraumatic stress disorder: A state-of- science review. Journal of Psychiatric Research 2006; 40: 1-21. (available online at www.sciencedirect.com)

North CS, Kawasaki A, Spitznagel EL, Hong BA. The course of PTSD, major depression, substance abuse, and somatization after a natural disaster. Journal of Nervous and Mental Disease 2004; 192 (12): 823-829.

North CS, Tivis L, McMillen JC, Pfefferbaum B, Spitznagel EL, Cox J, Nixon S, Bunch KP, Smith EM. Psychiatric disorders in rescue workers after the Oklahoma City bombing. American Journal Psychiatry 2002;159:857-59.

North CS, Pollio DE, Pfefferbaum B, Megivern D, Vythilingam M, Westerhaus E, Martin GJ, Hong BA. Concerns of Capitol Hill staff workers after bioterrorism: focus discussions of authorities' response. Journal of Nervous and Mental Disorders 2005;193 (8):523-7. 
North CS, Pollio DE, Pfefferbaum B, Megivern D, Vythilingham M, Westerhaus E, Martin GJ, Hong BA. Capitol hill staff workers' experiences of bioterrorism: qualitative findings from focus groups. Journal of Traumatic Stress 2005; 18 (1):79-88.

Pfefferbaum B, North CS, Doughty DE, Pfefferbaum RL, Dumount CE, Gurwitch RH, Ndetei D. Trauma, grief and depression in Nairobi children after the 1998 bombing of the American Embassy. Death Studies 2006; 30 (6): 561-77.

Pfefferbaum B, Tucker P, North CS, Jeon-Slaughter H, Kent AT, Schorr JK, Wilson TG, Bunch K. Persistent physiological reactivity in a pilot study of partners of firefighters after a terrorist attack. Journal of Nervous and Mental Disease 2006; 194 (2): 128-131.

Pile JC, Malone JD, Eitzen EM, Friedlander AM. Anthrax: a potential biological warfare agent. Archives Internal Medicine 1998; 158:429-434.

Timmer S, Amundson DE, Malone JD. Hypersensitivity pneumonitis following anthrax vaccination. Chest 2002;122:741-745.

Tucker PM, Pfefferbaum B, North CS, Kent A, Burgin CE, Parker DE, Hossain A, Jeon-Slaughter H, Trautman RP. Physiologic reactivity despite emotional resilience several years after direct exposure to terrorism. American Journal of Psychiatry 2007;64:230-235.

Wild MA, Xin H, Maruyama T, Nolan MJ, Calveley PM, Malone JD, Wallace MR, Bowdish KS. Human antibodies from immunized donors are protective against anthrax toxin in vivo. Nature Biotechology 2003;21:1305-6. 


\section{Appendix F - Workshop Registrants}

\author{
Ken Almond \\ IBRD Site Manager \\ Cubic Applications, Inc \\ (858) 810-5749 \\ Ken.almond@cubic.com
}

Charles Axton

Disaster Assistance Division Director

FEMA Region 10

Charles.axton@dhs.gov

\section{Ken Back}

Emergency Preparedness Director

Washington State Dept. of Health

(360) 236-4534

Ken.back@doh.wa.gov

\section{Steve Bailey}

Director

Pierce County Emergency Management (253) 798-6595

Sbailey@co.pierce.wa.us

\section{Matthew Bernard \\ RTT Coordinator \\ USCG \\ (206) 220-7215 \\ Matthew.p.bernard@uscg.mil \\ Diane Bonne \\ Regional Catastrophic Preparedness \\ Program Manager \\ City of Seattle \\ (206) 733-9551 \\ Diane.bonne@seattle.gov}

\section{Rick Buell}

Regional Emergency Coordinator

Department of Health and Human Services (206) 615-3600

Rick.Buell@hhs.gov

\section{Vince Cacanindin}

Emergency Response Planner

DHS/FEMA

(425) 487-4602

Vince.cacanindin@dhs.gov

\section{Craig Calhoun}

Senior Analyst

Cubic Application, Inc

(703) 719-7590

Craig.calhoun@cubic.com

\author{
Duane Caneva \\ Director, Medical Preparedness Policy \\ Whitehouse Homeland Security Council \\ (202) 456-2171 \\ DCaneva@who.eop.gov
}

Erica Canzler
Biodefense Coordinator
EPA
(202) 564-2359
Canzler.erica@epa.gov
Josie Clark
EPA NW Area Planner
EPA Region 10
(206) 553-6239
Clark.josie@epa.gov

Rebecca Clark

Emergency Preparedness/Urban Area

Security Initiative Coordinator

Bellevue Emergency Management

(425) 452-4109

rclark@bellevuewa.gov

Andrew Cleaves

Exercise Specialist

FEMA Region 10

(425) 487-4732

Andrew.cleaves@gmail.com

\section{Charles Cordova}

Captain

Seattle Fire

(206) 291-7073

Charles.cordova@seattle.gov

\section{Jonathan Cothran}

CTR Sr. CBRN Analyst

JPM Guardian

(571) 303-3095

Jonathan.cothran@taurigroup.com

\section{Katie Crockett \\ DTRA A\&AS}

(571) 303-2049

\section{Katie.crockett@taurigroup.com}

\section{Scott Decker}

Senior Consultant

$\mathrm{CH} 2 \mathrm{Mhill}$

(425) 647-7808

Scott.decker@.ch2m.com 
Louis Dooley

Pierce County Emergency Management (253) 798-2209

Idooley@co.pierce.wa.us

\section{Rodger Edington}

Medical Services Officer

Tacoma Fire Department

(253) 591-5705

Redingto@ci.tacoma.wa.us

\section{Wayne Einfeld \\ Project Manager \\ Sandia National Laboratory \\ (505) 263-5420 \\ weinfel@sandia.gov}

\section{Chris Field}

Manager, EPA Emergency Response Program

EPA Region 10

(206) 553-1674

Field.chris@epamail.epa.gov

\section{Raymond Fleck}

Senior Inspector

US Marshal Service

(253) 261-3723

Raymond.fleck@usdoj.gov

\section{Wendy Freitag}

Corporate Relations Liaison

Washington Emergency Management

(253) 512-7308

w.Freitag@emd.wa.gov

\section{Robin Friedman}

Director

King County Emergency Management

(206) 205-4060

Robin.friedman@kingcounty.gov

\section{Kathleen Gleaves}

Emergency Manager

Port of Seattle

(206) 728-3153

Gleaves.k@portseattle.org

\section{Bobby Goodfellow}

DHS Science and Technology Directorate (202) 254-6726

Robert.goodfellow@associates.dhs.gov

\section{Brandon Hardenbrook}

Deputy Director

PNWER

(206) 443-7723

Brandon@pnwer.org

\section{Kurt Hardin}

Mitigation, Response and Recovery Unit Manager Washington State Emergency Management (253) 512-7061

\section{k.hardin@emd.wa.gov}

\section{Roy Harrington}

Emergency Management

King County Metro Transit

(206) 263-6505

Roy.harrington@kingcounty.gov

\section{A. Scott Heinze}

Principal

Heinze and Associates, LLC

(253) 459-0328

scott@heinzellc.com

Joseph Hesbrook

Regional Integration Branch Chief

FEMA Region 10

(425) 487-4728

Joseph.hesbrook@dhs.gov

\section{Roger Hieb}

Programs Unit Manager

Washington State Emergency Management

(253) 512-7042

r.hieb@emd.wa.gov

\section{John Himmel}

Emergency Manager

Washington State Department of Transportation (360) 705-7973

himmelj@wsdot.wa.gov

\section{Eric Holdeman}

Principal

ICF International

(253) 848-5095

eholdeman@icfi.com

\section{David Hunsinger}

Deputy Administrator, FEMA Region X

(425) 487-4604

\section{Dennis.hunsinger@dhs.gov}

\section{Debra Jelcick}

Sergeant

Seattle Police Department

(206) 684-0469

Debbie.jelcick@seattle.gov 
Richard Jenkins

Defense Coordinating Officer,

Region X

USARNORTH

(425) 487-4790

Richard-jenkins@us.army.mil

\section{Sandra Johnson}

Emergency Management Coordinator

Thurston County

(360) 754-3360

johnsons@co.thurston.wa.us

\section{Moses Kamai}

Chief, Knowledge System Architect

Cubic Applications, Inc

(703) 924-3050 ext. 5108

Moses.kamai@cubic.com

\section{James Kane}

Plans Officer

US Army Garrison, Fort Lewis

(253) 967-0488

James.kane2@.conus.army.mil

\section{Jennifer Keizer}

Assistant Emergency Manager

City of Kent

(253) 856-4342

jdkeizer@ci.kent.wa.us

\section{Heather Kelly}

Emergency Manager

King County Office of Emergency Management (206) 205-4034

\section{Heather.kelly@kingcounty.gov}

\section{David Kerchner}

Regional Emergency Coordinator

HHS ASPR

(206) 615-2506

\section{David.kerschner@hhs.gov}

\section{Ann Lesperance}

Deputy Director, NW Regional Technology Center for Homeland Security

PNNL

(206) 528-3223

Ann.lesperance@pnl.gov

\section{Michael Loehr}

Preparedness Director

Seattle/King County Public Health

(206) 263-8687

Michael.loehr@kingcounty.gov

\section{Erika Lund}

Recovery Coordinator

Seattle Office of Emergency Management (206) 233-5089

Erika.lund@seattle.gov

\section{Regina Lundgren}

Communication Consultant

Lundgren Consulting

(509) 582-6995

lundgren@owt.com

Ryan Madden

Program Manager

DTRA

(703) 767-3351

Ryan.madden@dtra.mil

\section{Sav Mancieri}

IBRD Task Leader

Lawrence Livermore National Laboratory

(925) 422-6920

Mancieri1@IInl.gov

\section{Patrick Massey}

Federal Preparedness Coordinator

FEMA Region 10

(425) 487-4704

Patrick.massey@dhs.gov

Thomas Mcgrann

Lawrence Livermore National Laboratory (925)

422-7760

Mcgrann1@|lnl.gov

\section{Deborah McKeton}

Div. Dir. NHSRC

EPA

(513) 487-2435

Mcketon.deborah@epa.gov

\section{Chris McLane}

Deputy Branch Chief/ Senior CBRN Analyst DoD Joint Staff J-8

(703) 602-0913

\section{Christoper.mclane@js.pentagon.mil}

\section{Don Mellor}

Homeland Security Analyst

Western Regional Medical Command, Madigan

Army Medical Center

(253) 968-4133

Donald.mellor@us.army.mil 
Luke Meyers

Program Coordinator II

Pierce County Emergency Management (253) 798-7843

Luke.meyers@co.pierce.wa.us

\section{Mike Midgley}

IBRD Functional Area Lead

Cubic Applications, Inc

(858) 810-5749

Mike.midgley@.cubic.com

\section{Gregory Miller}

Captain

Washington State Patrol

(360) 596-4134

Greg.miller@wsp.wa.gov

\section{Cynthia Miron}

Public Health Emergency Response Coordinator Tacoma Pierce County Health Department (253) 798-6556

cmiron@tpchd.org

\section{Matt Morrison}

Executive Director

PNWER

(206) 443-7723

matt@pnwer.org

\section{John Mower}

HLS Analyst

Cubic Applications, Inc.

(858) 810-5778

John.mower@cubic.com

\section{Lisa Northey}

Regional Catastrophic Preparedness Planner Seattle Emergency Management (206) 733-9552

Lisa.northey@seattle.gov

\section{Vernon Owens}

Emergency Preparedness Coordinator

Bellevue Emergency Management

(425) 452-6033

vowens@bellevuewa.gov

\section{Ken L. Parrish}

Program Manager, Emergency Management

Division, Pierce County Department

of Emergency Management

(253) 798-6597

kparris@co.pierce.wa.us

\section{John Pennington}

Director

Snohomish County Office

of Emergency Management

(425) 388-5079

John.pennington@snoco.org

\section{Dana Perkins}

Senior Science Advisor

Department of Health and Human Services, Office of the Assistant Secretary for Preparedness and

Response (202) 205-5715

Dana.perkins@hhs.gov

\section{Elizabeth Platt}

Planning

USCG

(206) 220-7343

\section{Elizabeth.t.platt@uscg.mil}

\section{Jim Price}

Training \& Development Specialist

Tacoma Pierce County Health Department

(253) 798-6548

jprice@tpchd.org

\section{Tyler Ray}

Homeland Security Emergency Manager

Washington State Patrol

(360) 704-2968

Tyler.ray@wsp.wa.gov

David Rees

Federal on Scene Coordinator

EPA

(206) 553-1808

Rees.david@epa.gov

Julie Sadovich

Director, EMMRI

DHS, Office of Health Affairs

(202) 254-5652

Julie.sadovich@dhs.gov

\section{Jessica Sandusky}

Security Policy Specialist

PNNL

(206) 528-3422

Jessica.sandusky@pnl.gov

\section{Fred Savaglio}

Program Director

Virginia Mason Medical Center

(206) 223-7534

Fred.savaglio@vmmc.org 


\section{Joan Scofield}

State Agency Liaison

Office of the Insurance Commissioner

(360) 725-7244

joans@oic.wa.gov

Jim Sheline
CBRNE Ops Spec
Fort Lewis DPTMS
(253) 967-0476
Jim.sheline@us.army.mil

\section{Darrell Small}

Deputy, Puget Sound Federal Coordinating Center National Disaster Medical System

(253) 968-3694

\section{Darrell.small@us.army.mil}

\section{Robert Soldier}

Emergency Planner

Federal Aviation Administration

(425) 227-1514

Robert.soldier@faa.gov

\section{Steve Stein}

Director, NW Regional Technology Center for Homeland Security

PNNL

(206) 528-3340

Steve.stein@pnl.gov

\section{Lisa Stephenson \\ Deputy US Marshal \\ US Marshal Service \\ (253) 302-8680 \\ Lisa.stephenson@usdoj.gov}

\section{Andrew Stevermer}

Regional Emergency Coordinator

HHS ASPR

(206) 396-1108

Andrew.stevermer@hhs.gov

\section{Nancy Suski}

Lawrence Livermore National Laboratory (925) 423-6046

Suski2@|lnl.gov

\section{Thomas Symonds}

Coordinator HLS/TEW

Pierce County Emergency Management (253) 798-7842

\section{tsymond@co.pierce.wa.us}

\section{Grant Tietje}

Emergency Manager

Seattle Office of Emergency Management (206) 684-7722

\section{Grant.tietje@seattle.gov}

Mark Tucker

Sandia National Laboratory

(505) 844-7264

mdtucke@sandia.gov

\author{
Nigel Turner \\ Public Health Manager \\ Tacoma-Pierce County Health Department \\ (253) 798-6057 \\ Niturner@tpchd.org \\ Jaki Upton \\ PNNL \\ (509) 375-4325 \\ Jaki.upton@.pnl.gov \\ Linda Vasta \\ Director, West Coast Operations \\ DHS S\&T/ Interagency and First Responder \\ Programs Division \\ (202) 680-4897 \\ Linda.vasta@.dhs.gov
}

\section{Ray Walker}

DTRA A\&AS

(571) 303-2061

Ray.walker@taurigroup.com

\section{Bill Webb}

Homeland Security Specialist

FEMA Region 10

(425) 487-4605

Bill.webb@dhs.gov

\section{Ute Weber}

Emergency Management Coordinator

City of Tacoma

(253) 594-7980

uweber@cityoftacoma.org

\section{Mark Williamson}

CBRNE Ops Spec

Fort Lewis DPTMS

(253) 967-0367

Mark.a.williamson@conus.army.mil

Jody Woodcock

Program Manager

Pierce County Emergency Management

(253) 798-7021

iwoodco@co.pierce.wa.us

\section{Lynn Yang}

Analyst

Sandia National Laboratory

(925) 294-4667

liyang@sandia.gov 


\section{Addressing the Federal-State-Local Interface Issues during a Catastrophic Event such as an Anthrax Attack}

SL Stein

AM Lesperance

JF Upton

February 2009

Prepared for the U.S. Department of Defense,

Defense Threat Reduction Agency under Contact IACRO\#B0844731 and the U.S. Department of Homeland Security

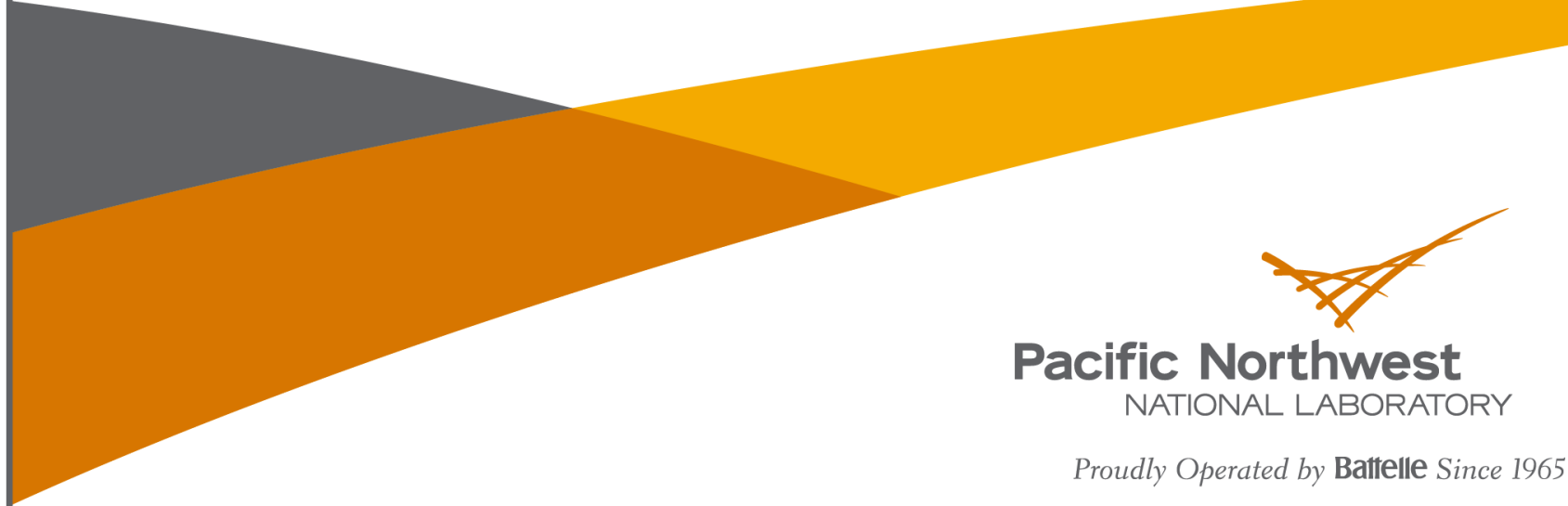

Supported by the Northwest Regional Technology Center for Homeland Security 


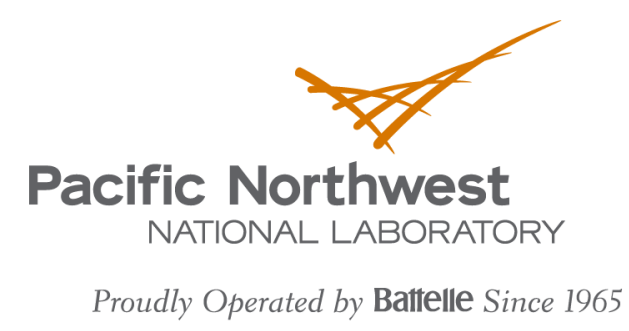

Supported by the Northwest Regional Technology Center for Homeland Security 
